\title{
A numerical study of back-building process in a quasistationary rainband with extreme rainfall over northern Taiwan during 11-12 June 2012
}

\author{
Chung-Chieh Wang ${ }^{1}$, Bing-Kui Chiou ${ }^{1}$, George Tai-Jen Chen ${ }^{2}$, Hung-Chi Kuo ${ }^{2}$, and Ching-Hwang Liu ${ }^{3}$ \\ ${ }^{1}$ Department of Earth Sciences, National Taiwan Normal University, Taipei, Taiwan \\ ${ }^{2}$ Department of Atmospheric Sciences, National Taiwan University, Taipei, Taiwan \\ ${ }^{3}$ Department of Atmospheric Sciences, Chinese Culture University, Taipei, Taiwan
}

Correspondence to: Chung-Chieh Wang (cwang@ntnu.edu.tw)

Received: 2 September 2015 - Published in Atmos. Chem. Phys. Discuss.: 19 November 2015

Revised: 29 July 2016 - Accepted: 2 September 2016 - Published: 29 September 2016

\begin{abstract}
During 11-12 June 2012, quasistationary linear mesoscale convective systems (MCSs) developed near northern Taiwan and produced extreme rainfall up to $510 \mathrm{~mm}$ and severe flooding in Taipei. In the midst of background forcing of low-level convergence, the back-building (BB) process in these MCSs contributed to the extreme rainfall and thus is investigated using a cloud-resolving model in the case study here. Specifically, as the cold pool mechanism is not responsible for the triggering of new BB cells in this subtropical event during the meiyu season, we seek answers to the question why the location about $15-30 \mathrm{~km}$ upstream from the old cell is still often more favorable for new cell initiation than other places in the MCS.

With a horizontal grid size of $1.5 \mathrm{~km}$, the linear MCS and the BB process in this case are successfully reproduced, and the latter is found to be influenced more by the thermodynamic and less by dynamic effects based on a detailed analysis of convective-scale pressure perturbations. During initiation in a background with convective instability and near-surface convergence, new cells are associated with positive (negative) buoyancy below (above) due to latent heating (adiabatic cooling), which represents a gradual destabilization. At the beginning, the new development is close to the old convection, which provides stronger warming below and additional cooling at mid-levels from evaporation of condensates in the downdraft at the rear flank, thus yielding a more rapid destabilization. This enhanced upward decrease in buoyancy at low levels eventually creates an upward perturbation pressure gradient force to drive further development along with the positive buoyancy itself. After the new
\end{abstract}

cell has gained sufficient strength, the old cell's rear-flank downdraft also acts to separate the new cell to about $20 \mathrm{~km}$ upstream. Therefore, the advantages of the location in the BB process can be explained even without the lifting at the leading edge of the cold outflow.

\section{Introduction}

As a common type of mesoscale convective systems (MCSs) with a lifespan around 3-12 h, organized rainbands such as squall lines are capable of producing persistent precipitation at high intensity, compared to ordinary, isolated, or scattered convection (e.g., Carbone, 1982; Bluestein and Jain, 1985; Rotunno et al., 1988; Browning, 1990; Houze et al., 1990; Chen and Chou, 1993; LeMone et al., 1998; Parker and Johnson, 2000; Doswell, 2001; Johnson and Mapes, 2001; Sun and Lee, 2002; Weisman and Rotunno, 2004; Meng et al., 2013). When such rainbands are slow moving and the embedded deep convective cells travel at small angles almost parallel to the line, multiple cells can pass through the same locations in succession to rapidly increase rainfall accumulation and the potential for flash floods (e.g., Maddox et al., 1979; Doswell et al., 1996; Brooks and Stensrud, 2000; Parker and Johnson, 2004). For the eastern two-thirds of the United States (US), Schumacher and Johnson (2005, 2006) found that $66 \%$ of extreme rainfall events there are caused by quasi-linear MCSs, among which $54 \%$ are produced by only two modes in organization. The training line-adjoining 
stratiform (TL/AS) type often forms along (or north of) an east-west (E-W) aligned, pre-existing slow-moving surface boundary (such as a front or a convergence line), and a series of embedded "training" cells move eastward (also Stevenson and Schumacher, 2014; Peters and Roebber, 2014; Peters and Schumacher, 2015). The second type is quasistationary back-building (BB) systems, which depend more on meso- and storm-scale forcing and processes. In BB lines, new cells form repeatedly on the upstream side at nearly the same location and then move downstream, making the line as a whole almost stationary (also Chappell, 1986; Corfidi et al., 1996). While some MCSs may possess characteristics of both types (Schumacher et al., 2011; Peters and Schumacher, 2015), the BB systems are typically smaller and more localized and thus more difficult to predict (e.g., Schumacher and Johnson, 2005).

To repeatedly trigger new cells in BB MCSs at midlatitudes, a well-known mechanism is through convectively generated outflow boundary from downdrafts, i.e., at the leading edge of the cold pool (or the gust front) that extends into the upwind side (e.g., Doswell et al., 1996; Parker and Johnson, 2000; Corfidi, 2003; Schumacher and Johnson, 2005, 2009; Houston and Wilhelmson, 2007; Moore et al., 2012), sometimes in conjunction with lifting along a frontal boundary (e.g., Schumacher et al., 2011). Similar mechanisms for the BB process are also found in some events in the East Asia (e.g., H. Wang et al., 2014; Jeong et al., 2016). However, toward lower latitudes such as the subtropics and tropics, the environments may be less conducive to cold pool development (e.g., Tompkins, 2001). Some studies of extreme rainfall events in South China and Taiwan have shown that surface-based cold air produced by previous convection that had dissipated for hours or even in the day before, when impinged by the moist monsoonal flow, in particular the lowlevel jet (LLJ), can act to trigger new convection in succession (e.g., Zhang and Zhang, 2012; Xu et al., 2012; C.C. Wang et al., 2014a; Luo et al., 2014). Such influences of "cold domes," however, are different from the lifting at gust fronts produced by coexisting, dissipating cells or those that had just dissipated, and the induced MCSs may be less organized if a linear forcing such as a front or low-level convergence zone is absent (e.g., Xu et al., 2012; C.-C. Wang et al., 2014b).

Many heavy rainfall events in Taiwan occur in the meiyu season (May-June), where repeated frontal passages affect the area during the transition period from northeasterly to southwesterly monsoon (e.g., Ding, 1992; Chen, 2004; Ding and Chan, 2005). When the meiyu front approaches Taiwan, both the MCSs near the front or those associated with the pre-frontal LLJ (south of the front) that impinges on the island can bring heavy rainfall (e.g., Chen and Yu, 1988; Kuo and Chen, 1990; Wang et al., 2005; C.-C. Wang et al., 2014a). Under such conditions, BB MCSs may still develop (e.g., Li et al., 1997), in environments that are not favorable for strong cold pools mainly due to high moisture content at low levels (e.g., Tompkins, 2001; James and Markowski, 2010; Yu and Chen, 2011). For these systems, the mechanism for upstream initiation of new cells at the end of the convective line, presumably also dominated by storm-scale processes as their US counterparts (Schumacher and Johnson, 2005), is not clear. Recently, the roles of pressure perturbation $\left(p^{\prime}\right)$, in particular the dynamical pressure perturbation ( $p_{\mathrm{d}}^{\prime}$; e.g., Rotunno and Klemp, 1982; Weisman and Klemp, 1986; Klemp, 1987, and many others), in the evolution of convective cells inside the E-W BB rainbands associated with Typhoon Morakot (2009) and extreme rainfall (e.g., Wang et al., 2012) are examined by Wang et al. (2015, hereafter referred to as WKJ15). They found that in the presence of an intense westerly LLJ, the interaction between updraft and vertical wind shear (e.g., Klemp, 1987) induces positive (negative) $p_{\mathrm{d}}^{\prime}$ at the western (eastern) flank of the updraft below the jet-core level (with westerly shear) but a reversed pattern above (with easterly shear) and thus an upward-directed perturbation pressure gradient force (PGF) at the western (rear) flank (see e.g., Fig. 6 of WKJ15). This leads to a slowdown in the propagation speed of mature cells and promotes cell merger inside the rainbands, as often observed in quasi-linear multi-cell MCSs. A reduced speed of old cell and positive $p_{\mathrm{d}}^{\prime}$ at its rear flank near the surface can also enhance convergence and contribute to upstream new cell initiation without the cold pool (WKJ15). Obviously, it is worth exploring whether a mechanism similar to the Morakot case also plays an important role in other BB rainbands near Taiwan in the meiyu season with the presence of a LLJ or whether some other processes are also involved. Thus, we seek to further understand and clarify the details of the BB process in the case below.

During 11-12 June 2012, both TL/AS and BB MCSs developed in succession near northern Taiwan and produced extreme rainfall up to $510 \mathrm{~mm}$ overnight (roughly during 14:00-24:00 UTC on 11 June, where LST $=\mathrm{UTC}+8 \mathrm{~h}$ ), in Taipei City and the surrounding metropolitan area. Many densely populated urban regions were flooded, and work was suspended for one day (12 June) in Taipei, the first ever in Taiwan in meiyu season due to heavy rainfall. Thus, this extreme rainfall event was rare in its total amount, duration, and location. As will be shown later, clear BB behavior occurred in the quasistationary MCSs and contributed to the extreme rainfall in northern Taiwan in this event, among other factors linked to frontal forcing and topographic effects. Thus, the BB process of the case herein is studied at the convective scale, mainly through numerical simulation using a cloudresolving model at a horizontal grid size of $1.5 \mathrm{~km}$. Below, the data used and the methodology employed are described in Sect. 2, and the extreme rainfall event of 11-12 June 2012, including its synoptic environment, is overviewed in Sect. 3. In Sect. 4, our simulation results are validated against observations, and further used to investigate the formation mechanism of the linear MCS and the BB process upstream from the old cells. This evolution is then compared with the initiation of an isolated cell in Sect. 5 to identify the impor- 
tant factors in the BB process, and finally the conclusion and summary of this work are given in Sect. 6.

\section{Data and methodology}

\subsection{Observational data}

In this study, the data used include weather maps from the Central Weather Bureau (CWB) of Taiwan and gridded final analyses $\left(0.5^{\circ} \times 0.5^{\circ}\right.$, every $\left.6 \mathrm{~h}\right)$ from the US National Oceanic and Atmospheric Administration (NOAA)/National Centers for Environmental Prediction (NCEP) at 26 levels from 1000 to $10 \mathrm{hPa}$ (including the surface level) covering the case period. The space-borne Advanced Scatterometer (ASCAT; Figa-Saldaña et al., 2002) observations are also used to assist the analysis of frontal position. For conditions in the pre-storm environment, the sounding at Panchiao (near Taipei City) is used. For the evolution of the MCS and the resulting rainfall, the vertical maximum indicator (VMI) composites of radar reflectivity and hourly data from the raingauge network (Hsu, 1998) in Taiwan, both provided by the CWB, are employed. The above observational data are used both for analysis and verification of model results.

\subsection{The Cloud-Resolving Storm Simulator (CReSS) and experiment}

CReSS is used for our numerical simulation. It is a cloudresolving model that employs a nonhydrostatic and compressible equation set and a height-based terrain-following vertical coordinate (Tsuboki and Sakakibara, 2002, 2007). Clouds are treated explicitly in CReSS using a bulk coldrain microphysical scheme (Lin et al., 1983; Cotton et al., 1986; Murakami, 1990; Ikawa and Saito, 1991; Murakami et al., 1994) with a total of six species (vapor, cloud water, cloud ice, rain, snow, and graupel). Sub-grid-scale processes parameterized include turbulent mixing in the planetary boundary layer, radiation, and surface momentum and energy fluxes (Kondo, 1976; Louis et al., 1981; Segami et al., 1989). With a single domain (no nesting), this model has been used to study a number of heavy rainfall events around Taiwan during the meiyu season (e.g., C.-C. Wang et al., 2005, 2011, 2014a, b; Wang and Huang, 2009) as well as for real-time forecasts (e.g., Wang et al., 2013, 2016a; Wang, 2015, 2016). The CReSS model is open to the research community upon request, and further details can be found in the works referenced above and at http://www.rain.hyarc. nagoya-u.ac.jp/ tsuboki/cress_html/index_cress_jpn.html.

In this study, the simulation is performed using a horizontal grid spacing of $1.5 \mathrm{~km}$ and a grid dimension $(x, y, z)$ of $1000 \times 800 \times 50$ points (cf. Fig. 1, Table 1). As already described, the NCEP $0.5^{\circ} \times 0.5^{\circ}$ gridded final analyses serve as the initial and boundary conditions (IC/BCs) of the model run from 12:00 UTC on 10 June to 12:00 UTC on 12 June 2012 (for $48 \mathrm{~h}$ ). At the lower boundary, real terrain at $30 \mathrm{~s}$

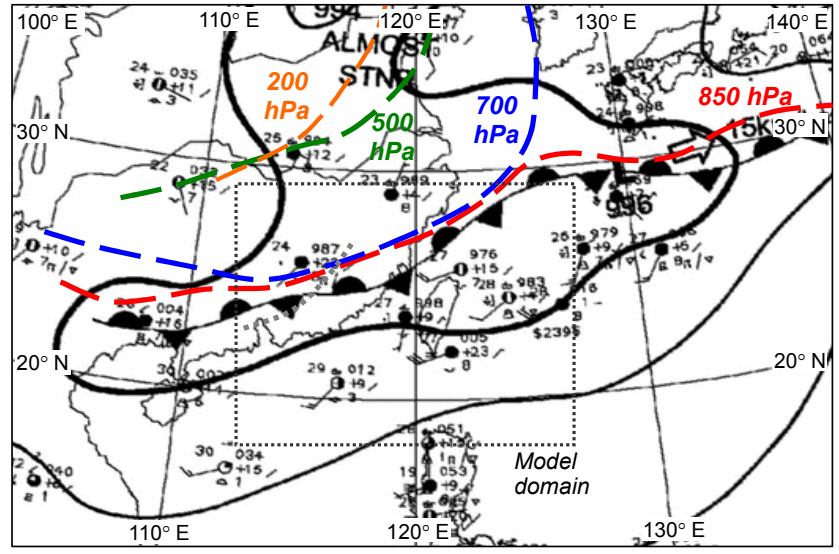

Figure 1. CWB surface analyses and positions of front/trough (or wind-shift line, thick dashed) at 850 (red), 700 (blue), 500 (green), and $200 \mathrm{hPa}$ (orange) at 12:00 UTC on 11 June 2012. The CReSS model domain is marked by the dotted box.

resolution (or $(1 / 120)^{\circ}$, roughly $\left.900 \mathrm{~m}\right)$ and observed weekly sea surface temperature (Reynolds et al., 2002) are provided. The model configuration and major aspects of the experiment are summarized in Table 1.

\subsection{Analysis of vertical momentum and pressure perturbations}

To investigate the $\mathrm{BB}$ process taking place in the present case using model outputs, the methods below, following Wilhelmson and Ogura (1972), Rotunno and Klemp (1982), Klemp (1987), and Parker and Johnson (2004), are used to perform analysis of vertical momentum and pressure perturbations. With the background environment assumed to be in hydrostatic equilibrium, the vertical momentum equation can be written as

$$
\frac{\mathrm{d} w}{\mathrm{~d} t}=-\frac{1}{\rho} \frac{\partial p^{\prime}}{\partial z}-\frac{\rho^{\prime}}{\rho} g+F_{z} \approx-\frac{1}{\rho_{0}} \frac{\partial p^{\prime}}{\partial z}-\frac{\rho^{\prime}}{\rho_{0}} g+F_{z},
$$

where all variables have their conventional meanings. Here, $\rho=\rho_{0}+\rho^{\prime}$, where $\rho_{0}$ is the background value and $\rho^{\prime}$ the perturbation part of $\rho, B=-g\left(\rho^{\prime} / \rho_{0}\right)$ is the buoyancy, and $F_{z}$ is the friction term by turbulent mixing. Thus, the vertical acceleration is driven by an imbalance among the perturbation PGF, buoyancy, and turbulent mixing. The buoyancy is constituted by the gaseous effect and the drag of all condensates, and can be expressed as

$B=-\frac{\rho^{\prime}}{\rho_{0}} g=g \frac{\theta_{\mathrm{v}}^{\prime}}{\theta_{\mathrm{v} 0}}-g \sum q_{x}$,

where $\theta_{\mathrm{v}}$ is the virtual potential temperature (and $\theta_{\mathrm{v}}=\theta_{\mathrm{v} 0}+$ $\left.\theta_{\mathrm{v}}^{\prime}\right)$ and its perturbation accounts for the gaseous effect, while $q_{x}$ denotes the mixing ratio of any condensate species.

The perturbation pressure $p^{\prime}$ can be divided into the dynamical and buoyant components as $p^{\prime}=p_{\mathrm{d}}^{\prime}+p_{\mathrm{b}}^{\prime}$, and the diagnostic pressure equations for the anelastic set, with friction 
Table 1. The CReSS model domain configuration and physics used in this study.

\begin{tabular}{ll}
\hline Projection & Lambert conformal (center at $120^{\circ} \mathrm{E}$, secant at 10 and $\left.40^{\circ} \mathrm{N}\right)$ \\
Grid spacing & $1.5 \mathrm{~km} \times 1.5 \mathrm{~km} \times 100-980 \mathrm{~m}(400 \mathrm{~m})^{*}$ \\
Dimension and size $(x, y, z)$ & $1000 \times 800 \times 50(1500 \mathrm{~km} \times 1200 \mathrm{~km} \times 20 \mathrm{~km})$ \\
IC/BCs & NCEP $0.5^{\circ} \times 0.5^{\circ}$ analyses $(26$ levels, every $6 \mathrm{~h})$ \\
Topography and sea surface temperature & Real at $(1 / 120)^{\circ}$ and weekly mean on $1^{\circ} \times 1^{\circ}$ grid \\
Integration period & $12: 00 \mathrm{UTC}$ on $10 \mathrm{June}$ to $12: 00 \mathrm{UTC}$ on $12 \mathrm{June} 2012(48 \mathrm{~h})$ \\
Output frequency & Every 15 min $($ every 5 min during $18: 00-24: 00 \mathrm{UTC}$ on $11 \mathrm{June})$ \\
Cloud microphysics & Bulk cold-rain scheme $(6$ species $)$ \\
Planetary boundary layer parameterization & 1.5 -order closure with prediction of turbulent kinetic energy \\
Surface processes & Energy/momentum fluxes, shortwave and longwave radiation \\
Substrate soil model & 41 levels, every $5 \mathrm{~cm}$ to $2 \mathrm{~m}$ deep \\
\hline
\end{tabular}

* The vertical grid spacing $(\Delta z)$ of CReSS is stretched (smallest at the bottom), and the averaged spacing is given in the parentheses.

omitted (e.g., Rotunno and Klemp, 1982; Parker and Johnson, 2004), are

$\nabla^{2} p_{\mathrm{b}}^{\prime}=\frac{\partial}{\partial z}\left(\rho_{0} B\right)$

and

$$
\begin{aligned}
\nabla^{2} p_{\mathrm{d}}^{\prime}= & -\rho_{0}\left[\left(\frac{\partial u}{\partial x}\right)^{2}+\left(\frac{\partial v}{\partial y}\right)^{2}+\left(\frac{\partial w}{\partial z}\right)^{2}\right. \\
& \left.-w^{2} \frac{\partial^{2}}{\partial z^{2}}\left(\ln \rho_{0}\right)\right]-2 \rho_{0}\left(\frac{\partial v}{\partial x} \frac{\partial u}{\partial y}+\frac{\partial u}{\partial z} \frac{\partial w}{\partial x}\right. \\
& \left.+\frac{\partial v}{\partial z} \frac{\partial w}{\partial y}\right)
\end{aligned}
$$

where $\nabla^{2}$ is the Laplacian operator. In both equations, a positive (negative) center in $\nabla^{2} p^{\prime}$ corresponds to a local minimum (maximum) in $p^{\prime}$ itself. Equation (3) states that $p_{\mathrm{b}}^{\prime}$ is related to the vertical gradient of the product of $\rho_{0}$ and $B$. On the right-hand side of Eq. (4), inside the brackets are extension terms which imply maximized $p_{\mathrm{d}}^{\prime}$ in regions of nonzero divergence or deformation. The other terms inside the parentheses are shearing terms and imply minimized $p_{\mathrm{d}}^{\prime}$ in regions of nonzero vorticity (Parker and Johnson, 2004). The shearing effects include those related to vertical wind shear $(\partial u / \partial z$ and $\partial v / \partial z$ ) associated with the LLJ, as reviewed in Sect. 1 for the Morakot case. After $\nabla^{2} p_{\mathrm{b}}^{\prime}$ or $\nabla^{2} p_{\mathrm{d}}^{\prime}$ is obtained from Eqs. (3) or (4), the relaxation method is used to solve the associated pressure perturbation through iteration (see Appendix A for details).

To provide additional verification, a second, independent method is also used in this study to compute $p^{\prime}$ as in WKJ15. In this method, $p^{\prime}$ is separated from its background pressure $\left(p_{0}\right)$, defined as

$p_{0}(x, y, z, t)=\langle p\rangle(x, y, z)+\Delta p(z, t)$,

where $\langle p\rangle$ is the time-averaged pressure over a fixed period, and $\Delta p$ is the deviation of the areal-mean pressure $\bar{p}$ at any given instant from its time mean $\langle\bar{p}\rangle$, such that

$\Delta p(z, t)=\bar{p}(z, t)-\langle\bar{p}\rangle(z)$.
Thus, the gradual decrease of the areal-mean pressure with time as the meiyu front approaches from the north is reflected in $\Delta p$ and taken into account in $p_{0}$ besides the spatial variation in (time-averaged) mean $p$ (cf. Eq. 5). Then, $p^{\prime}$ is computed simply as

$p^{\prime}(x, y, z, t)=p(x, y, z, t)-p_{0}(x, y, z, t)$.

Referred to as the separation method, it is also applied to other variables to separate the perturbation and the background where needed, such as for $\rho$ and $\theta_{\mathrm{v}}$ in Eqs. (1) and (2), as well as potential temperature $\theta$ and horizontal wind components $u$ and $v$.

\section{Case overview}

\subsection{Synoptic and storm environment}

In this section, the synoptic conditions and the $\mathrm{BB}$ rainbands responsible for the extreme rainfall are described. Figure 1 shows the surface weather map at 12:00 UTC on 11 June 2012 , about $2 \mathrm{~h}$ before heavy rainfall started in northern Taiwan. Extending from the East China Sea to southern China (ENE-WSW), the meiyu front was about $130 \mathrm{~km}$ north of Taiwan, with almost an upright structure up to $700 \mathrm{hPa}$ in the area. Based mainly on wind field since the meiyu front near Taiwan is often associated with strong cyclonic shear vorticity but only weak thermal contrast (e.g., Kuo and Anthes, 1982; Chen et al., 2003; Wang et al., 2016b), the frontal position at this time in the NCEP $950 \mathrm{hPa}$ analysis (Fig. 2a) is in agreement with the surface map, as is the ASCAT observation at 13:00 UTC (Fig. 2e). In the NCEP analysis, the strong southwesterly LLJ south of the front over the Taiwan Strait and off southeastern Taiwan is also revealed. While the LLJ reaches $20 \mathrm{~m} \mathrm{~s}^{-1}$ in maximum speed (at $950 \mathrm{hPa}$ ), the axis over the strait points toward northwestern Taiwan between the front and the island's topography (Fig. 2a). When the meiyu front approaches and the prevailing southwesterly flow strengthens (mainly due to an increased pressure gradient), such a configuration is often produced in response 

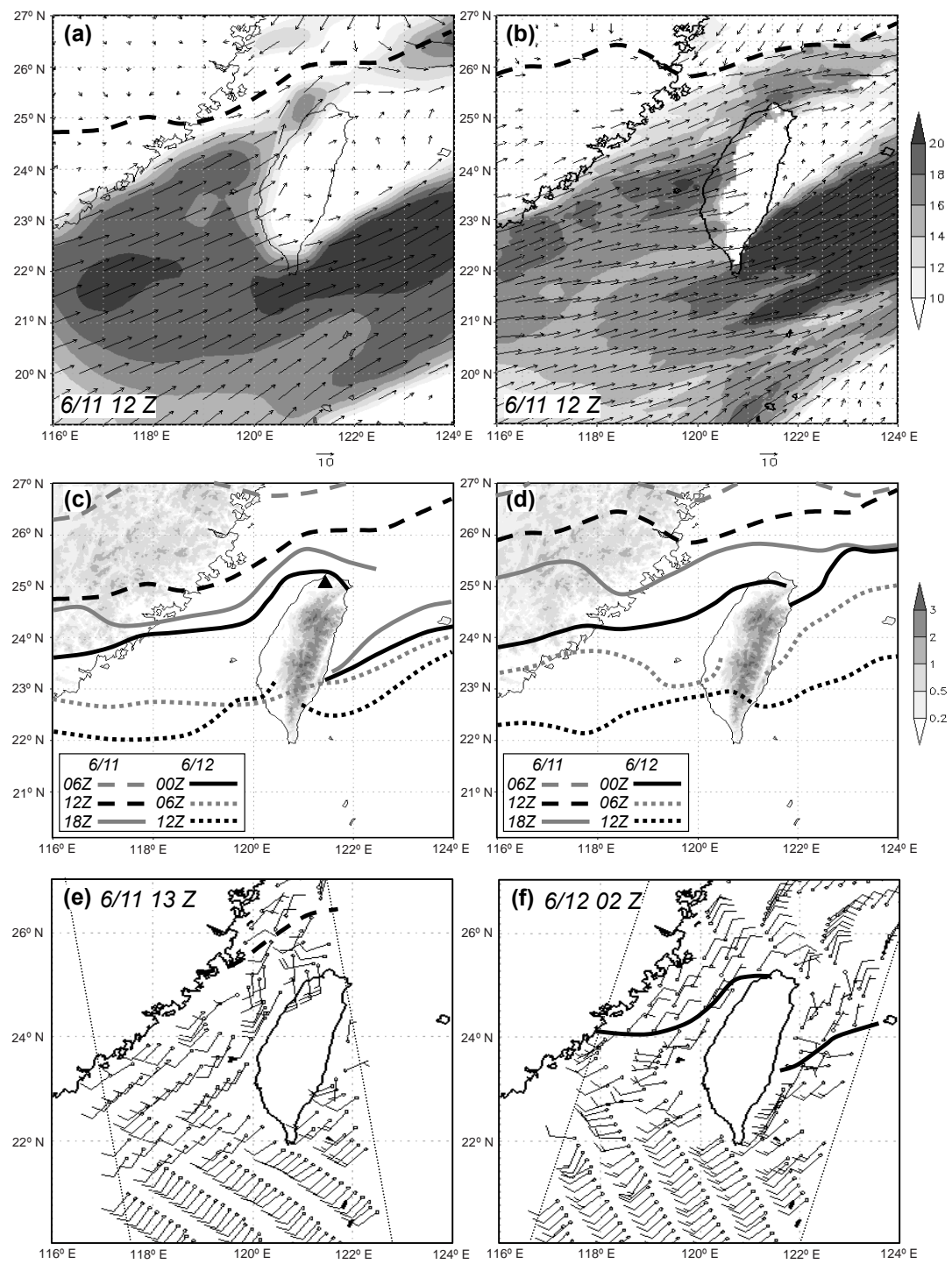

Figure 2. (a) NCEP $\left(0.5^{\circ}\right) 950 \mathrm{hPa}$ analysis and (b) CReSS simulation of horizontal winds $\left(\mathrm{m} \mathrm{s}^{-1}\right.$, speed shaded, scale to the right) at $z=549 \mathrm{~m}$ at 12:00 UTC on 11 June 2012, with frontal position marked (thick dashed lines). (c, d) Frontal positions every $6 \mathrm{~h}$ from 06:00 UTC on 11 June to 12:00 UTC on 12 June 2012 (c) at $950 \mathrm{hPa}$ in NCEP analyses and (d) at $z=549 \mathrm{~m}$ in model (see legend for line color and style), overlaid with topography (km, shading, scale to the right). The triangle in panel (c) marks the location of Panchiao sounding in Fig. 3. (e, f) ASCAT oceanic winds $\left(\mathrm{m} \mathrm{s}^{-1}\right)$ near Taiwan at (e) 13:00 UTC on 11 June and (f) 02:00 UTC on 12 June 2012, with surface frontal position analyzed.

to flow splitting due to terrain blocking and the subsequent channeling, confluence, and acceleration, with local wind maxima, i.e., barrier jets, near the two ends of Taiwan (e.g., Li and Chen, 1998; Wang ad Chen, 2002; Chen et al., 2005). For the one in northern Taiwan Strait (Fig. 2a), in particular, the low-level convergence (from confluence) associated with the barrier jet can provide the forcing for quasi-linear MCSs near or south of the front (e.g., Yeh and Chen, 2002; Wang et al., 2005). The NCEP analyses every $6 \mathrm{~h}$ shows that the $950 \mathrm{hPa}$ front reached northern Taiwan near 00:00 UTC on 12 June (Fig. 2c), also consistent with ASCAT data at
02:00 UTC (Fig. 2f). Afterward, as the rainfall in northern Taiwan gradually weakened (cf. Figs. 4 and 9, to be discussed later), the meiyu front advanced rapidly across Taiwan and reached about $23^{\circ} \mathrm{N}$ within $6 \mathrm{~h}$ (Fig. 2c).

The Panchiao sounding (Fig. 3) in the Taipei metropolitan area (cf. Fig. 2c) at 12:00 UTC on 11 June indicated very strong southwesterly flow throughout the lower troposphere, with a peak of $25 \mathrm{~m} \mathrm{~s}^{-1}$ near $925 \mathrm{hPa}$, consistent with the barrier jet in Fig. 2a (e.g., Li and Chen, 1998; Chen et al., 2005). Near the surface, the temperature lapse rate was close to dry adiabat and indicated a well-mixed pro- 


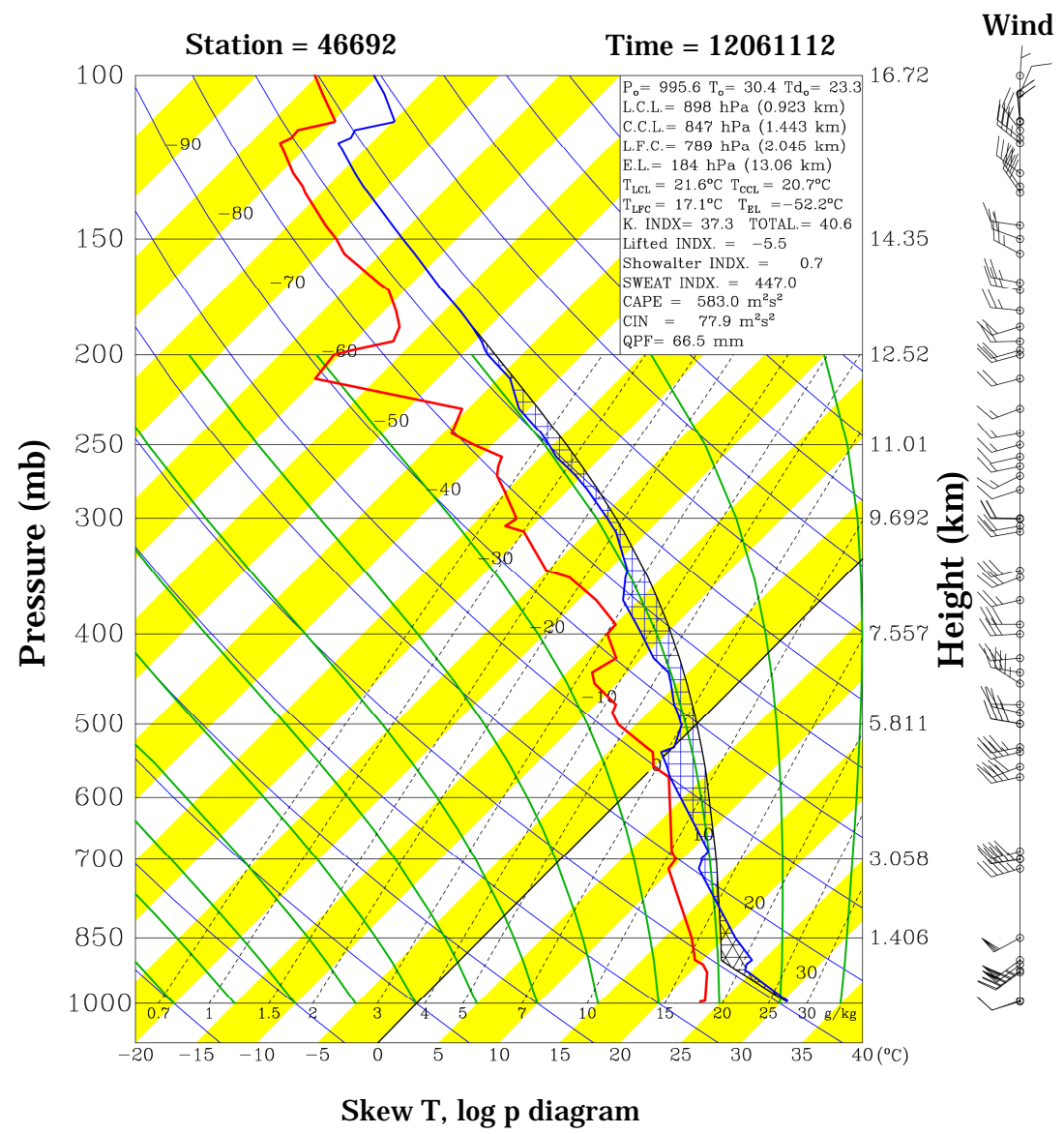

Figure 3. Thermodynamic (skew $T-\log p$ ) diagram for the sounding taken at Panchiao (46692, cf. Fig. 2c for location) at 12:00 UTC on 11 June 2012. For winds, full (half) barbs denote $10(5) \mathrm{kts}\left(1 \mathrm{kt}=0.5144 \mathrm{~m} \mathrm{~s}^{-1}\right)$.

file, while that further aloft was less steep but still mostly exceeded the moist adiabat, indicating conditional instability up to about $550 \mathrm{hPa}$. The convective available potential energy (CAPE) was $583 \mathrm{~J} \mathrm{~kg}^{-1}$ and sufficient to support deep convection if the air parcel could overcome the convective inhibition (CIN) of $78 \mathrm{~J} \mathrm{~kg}^{-1}$ to reach the level of free convection at $789 \mathrm{hPa}$. Obviously, these conditions were soon met since heavy rainfall did occur in Taipei. Note also that the humidity was quite high below about $550 \mathrm{hPa}$, and a dry layer did not exist throughout the troposphere. Thus, with instability and low-level convergence, the strong, deep, and moisture-laden southwesterly flow near and to the south of the approaching meiyu front was clearly very favorable for active convection and substantial rainfall (e.g., Jou and Deng, 1992; C.-C. Wang et al., 2014a).

\subsection{The back-building rainband with extreme rainfall}

Figure 4 presents the composite VMI radar reflectivity from the ground-based radars in Taiwan at $1 \mathrm{~h}$ intervals and depicts the evolution of the rainbands causing the extreme rainfall in northern Taiwan. At 12:00 UTC on 11 June (Fig. 4a), an in- tense ENE-WSW-oriented squall line, with peak reflectivity in convective elements $\geq 50 \mathrm{dBZ}$, already formed and was approaching northern Taiwan to within about $30 \mathrm{~km}$, i.e., at some $80-100 \mathrm{~km}$ ahead of the surface meiyu front (cf. Figs. 1 and 2a). With a bulging middle section and trailing stratiform, the squall line moved southward at about $15 \mathrm{~km} \mathrm{~h}^{-1}$ and into northern Taiwan by 14:00 UTC (Fig. 4b and c). During the following hours through 18:00 UTC, this squall line continued to advance slowly and into $25^{\circ} \mathrm{N}$, so that much of northern Taiwan was covered by echoes with high reflectivity (Fig. $4 \mathrm{~d}-\mathrm{g}$ ), while the stratiform region gradually moved eastward, in agreement with the upper-level wind (cf. Fig. 3). After 18:00 UTC, the convection through northern Taiwan evolved into a narrow line that remained quasistationary for hours until 23:00 UTC (Fig. 4g-1), with evident new development toward the west, i.e., back-building behavior (to be detailed later). Eventually, this linear MCS started to move south slowly and gradually away from the Taipei area after 00:00 UTC on 12 June (Fig. 4m-o), likely in conjunction with the surface front with the arrival of the northeasterly flow (cf. Fig. 2c and f). During the entire period of Fig. 4, the mountain interiors in central and southern Tai- 

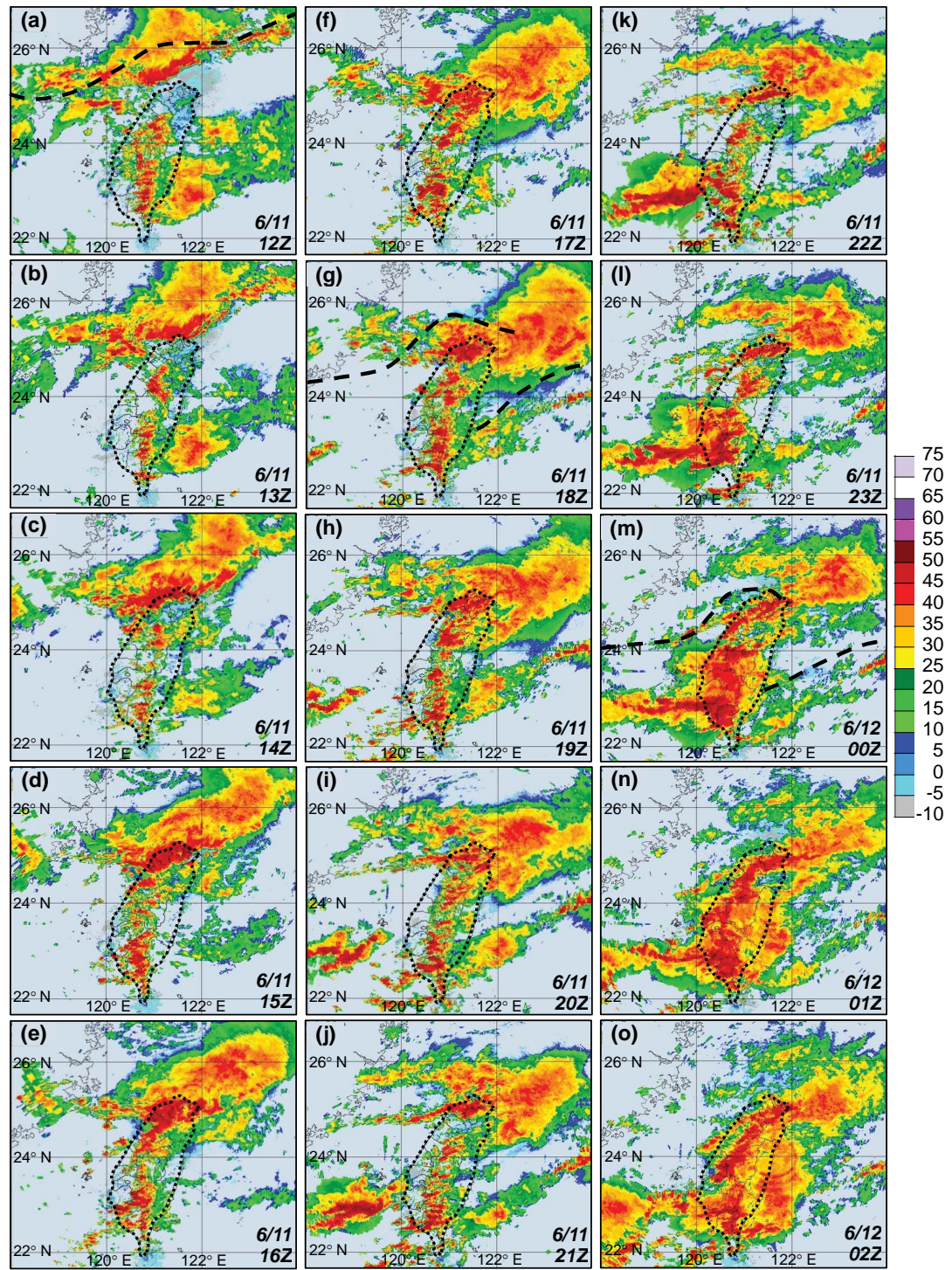

Figure 4. Composite VMI radar reflectivity (dBZ, color, scale to the right) over the Taiwan area at $1 \mathrm{~h}$ intervals from (a) 12:00 UTC on 11 June to (i) 02:00 UTC on 12 June 2012. The outline of Taiwan is highlighted (thick dotted lines) and the surface frontal position is plotted at synoptic times (thick dashed lines).

wan also received continuous rainfall from forced uplift of the strong LLJ by the topography (cf. Fig. 2a and c), and another squall line also approached southern Taiwan from the west and made landfall near 22:00 UTC on 11 June (Fig. 4io). Nonetheless, the reflectivity over northern Taiwan was both very active and lengthy, and was produced by two types of MCSs: the first was the squall line before 18:00 UTC on 11 June and reminiscent to a TL/AS system, and the second was the quasistationary BB MCS after 18:00 UTC (Fig. 4).

The distributions of $6 \mathrm{~h}$ accumulated rainfall during 12:00-18:00 and 18:00-24:00 UTC on 11 June are shown in Fig. 5a and b. While three distinct rainfall centers over northern, central, and southern Taiwan were produced in each period, the amount over northern Taiwan was the highest. The rainfall during 12:00-18:00 UTC was maximized along the northwestern coast and decreased inland (Fig. 5a), consistent with the MCS that moved in from the ocean (cf. Fig. 4). In contrast, the rainfall was more concentrated during 18:0024:00 UTC with almost an E-W alignment, and the center was right near the Taipei City (Fig. 5b). The peak amount during this later $6 \mathrm{~h}$ period was $311 \mathrm{~mm}$, and an extreme value of $510 \mathrm{~mm}$ was recorded overnight from the entire event. It is perhaps worthy to note that the mountainous interior in central and southern Taiwan also received heavy rainfall since about 00:00 UTC on 10 June (presumably due to forced uplift), but little rain fell over northern Taiwan prior to the current event. 

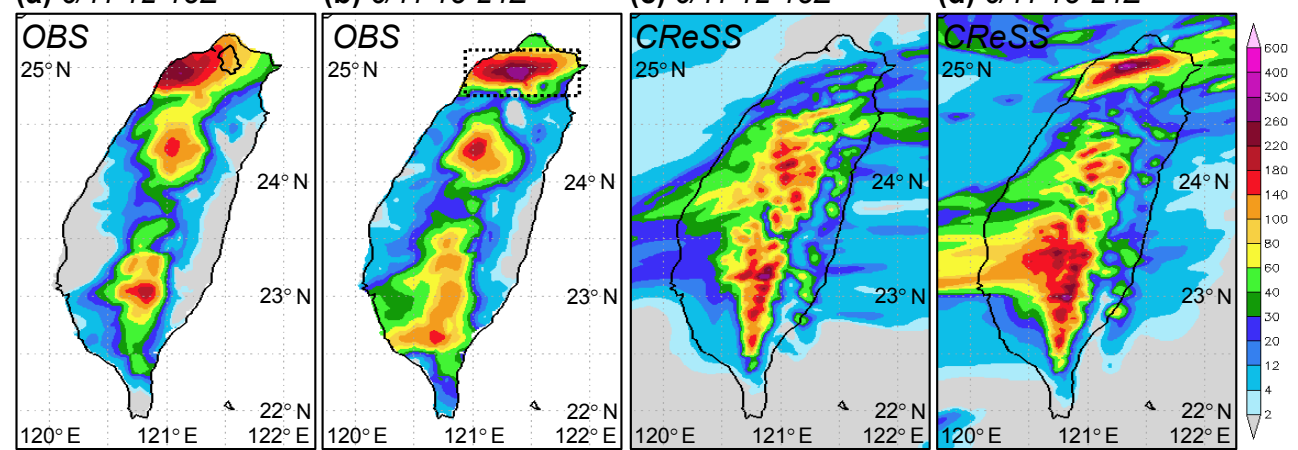

Figure 5. Distribution of observed $6 \mathrm{~h}$ accumulated rainfall (mm, color, scale to the right) over Taiwan during (a) 12:00-18:00 UTC and (b) 18:00-24:00 UTC on 11 June 2012. The Taipei City boundary is depicted in panel (a), and the dotted box in panel (b) shows the region used in Fig. 8 for rainfall average. (c, d) As in panels $(\mathbf{a}, \mathbf{b})$, but showing model-simulated rainfall over Taiwan and the surrounding oceans.

While back-building likely also occurred in the TL/AStype squall line, such behaviors in the quasistationary rainband after 18:00 were well depicted by the radar VMI reflectivity every $10 \mathrm{~min}$ (Fig. 6). As marked by the short arrows, frequent $\mathrm{BB}$ activities can be spotted at the western end of the convective line or west of existing mature cells, and some of them were quite close to the northwestern coast of Taiwan. After formation, they moved at small angles from the ENE-WSW-oriented quasistationary line, repeatedly across northern Taiwan with frequent cell mergers similar to those in WKJ15 (Fig. 6). The resulted rainfall in Fig. 5b, with the maximum located inland near Taipei, also implies that many cells matured after they moved onshore instead of over the ocean prior to landfall. Since the length of the line with active cells upstream from Taipei is about $160 \mathrm{~km}$ and most cells traveled at the speed range of $60-80 \mathrm{~km} \mathrm{~h}^{-1}$ in Fig. 6, the heavy rainfall would last only $2-2.5 \mathrm{~h}$ and much shorter than in reality (cf. Fig. 5) if there were no new developments westward along the line.

In extreme events, there are often multiple factors of different scales working in synergy to lead to their occurrence. This is also true in the present case, and the scenario leading to heavy rainfall can be quite complicated. While the large and synoptic-scale conditions provided a favorable background (Figs. 1-3), the two MCSs developed south of the approaching meiyu front, in close proximity to the area of terrain-influenced low-level convergence (and the barrier jet) near northern Taiwan (Figs. 2a, c, e, and f, and 4). In Figs. 4 and 6 , the convective lines even exhibited characteristics of multiple lines at times, possibly linked to gravity-wave activities (e.g., Yang and Houze, 1995; Fovell et al., 2006). While the formation mechanism of the quasi-linear MCSs (the second one in specific) and the roles played by both the meiyu front and the topography will be discussed and clarified (Sect. 4.2), the BB process at the convective scale was also a contributing factor to the extreme rainfall, especially during the later $6 \mathrm{~h}$ period after 18:00 UTC (Fig. 6). Also, as typical in many events, the new BB cell is often found to develop about $15-30 \mathrm{~km}$ upstream from an old cell in Fig. 6. Thus, why this particular spot has an advantage for new cell initiation compared to other locations without a nearby old cell is the scientific question that we wish to answer and the main focus of this case study. This specific question (and the formation mechanism of the MCSs) will be addressed through our numerical simulation results below.

\section{Results of model simulation}

\subsection{Model result validation}

As described in Sect. 2.2, our CReSS model simulation was performed from 12:00 UTC on 10 June 2012 for $48 \mathrm{~h}$ using NCEP $\left(0.5^{\circ}\right)$ final analyses as IC/BCs, with a horizontal grid spacing of $1.5 \mathrm{~km}$. The simulated winds and the front at an elevation of $549 \mathrm{~m}$ (close to $950 \mathrm{hPa}$ ) at 12:00 UTC on 11 June $(t=24 \mathrm{~h})$ and frontal positions every $6 \mathrm{~h}$ are shown in Fig. $2 b$ and d. Compared to the observation and NCEP analyses (Figs. 1, 2a, and e), the simulated front in Fig. $2 b$ is slightly too north, especially west of $120.5^{\circ} \mathrm{E}$ and over land in southeastern China, but the prefrontal LLJ is well captured, including the strong winds (barrier jet) near northern Taiwan. Linked to the position error of the front at 12:00 UTC, the modeled front is also too north at 18:00 UTC, but its western segment over the strait advanced southward more rapidly to catch up with the NCEP analyses during the next $6 \mathrm{~h}$ (Fig. $2 \mathrm{c}$ and d). The segment east of Taiwan, however, is still too north at 00:00 UTC, 12 June (cf. Fig. 2f), and the position error there does not improve until about $12 \mathrm{~h}$ later (Fig. 2c and d).

The model-simulated surface winds at $10 \mathrm{~m}$ height and column-maximum mixing ratio of total precipitation every $2 \mathrm{~h}$ during 12:00-22:00 UTC on 11 June are shown in Fig. 7, which can be compared with the radar composites in Fig. 4. In the model, the squall line before 18:00 UTC is along and 


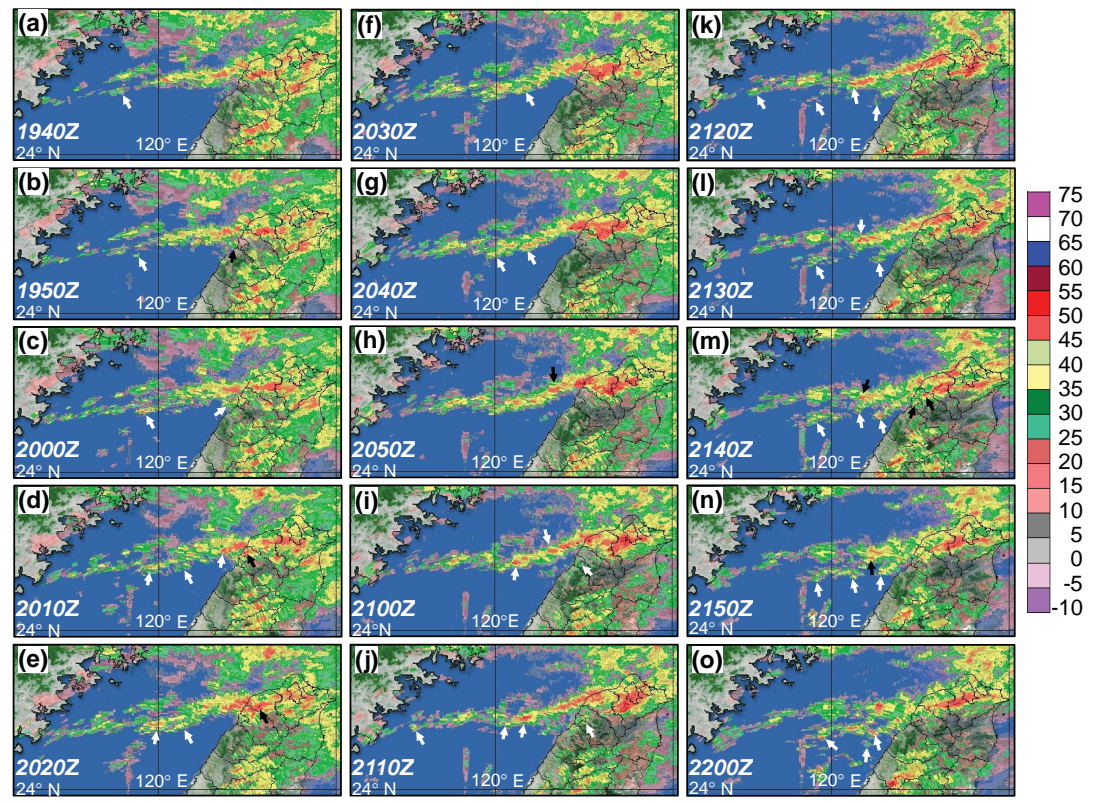

Figure 6. As in Fig. 4, but showing reflectivity over northern Taiwan and the upstream area every 10 min from (a) 19:40 UTC to (o) 22:00 UTC on 11 June 2012 using a different set of colors. The arrows mark the initiation or strengthening of back-building cells, off the western end of a rainband or upstream from an old cell.

to the north of the near-surface front (Fig. 7a-d) and different from the training-line system ahead of the front in the observation. Thus, the simulation of the first MCS was not ideal in location, apparently linked to the frontal position error discussed earlier. However, the quasistationary MCS over northern Taiwan since 18:00 UTC, with intense convective cells near Taipei, and the second squall line over the southern strait are both nicely captured in the model as the front advanced south (Fig. 7d-f). As a result, the rainfall simulation in northern Taiwan during 18:00-24:00 UTC, with a peak amount of $312 \mathrm{~mm}$, is in close agreement with the observation (Fig. $5 \mathrm{~b}$ and d), while that during the preceding $6 \mathrm{~h}$ was not (Fig. 5a and c). Similar results are also revealed by hourly histogram of rainfall in Fig. 8, averaged inside the elongated box depicted in Fig. 5b. The rainfall in northern Taiwan was much better simulated in magnitude and variation in time after 18:00 UTC, 11 June (Fig. 8), although the areal-averaged intensity in the model is somewhat lower because the simulated rain belt is narrower than the one observed (Fig. 5b and d). Also, the model predicted more rainfall than observed over the mountains in southern Taiwan (Fig. 5), indicating that the flow over the terrain might be somewhat overestimated, though this is not our focus here.

\subsection{Formation of the quasi-linear MCS}

The more detailed distributions of horizontal winds and convergence/divergence near the surface at $312 \mathrm{~m}$ from 18:30 to 21:00 UTC on 11 June 2012 in the model are shown in Fig. 9. With a wavy pattern and strong convergence along most of its length, the near-surface meiyu front (black dotted curves) is north of Taiwan but gradually approaches during this period. Consistent with Figs. 1, 2, 6, and 7, the quasi-linear and stationary MCSs, in contrast, developed south of the front near $25^{\circ} \mathrm{N}$. As the front advances, their distance decreased from about $90 \mathrm{~km}$ at 18:30 UTC to $30 \mathrm{~km}$ at 21:00 UTC (Fig. 9), and in the observation the front only caught up with the prefrontal MCS after 00:00 UTC on 12 June as mentioned (cf. Figs. $2 \mathrm{c}$ and $4 \mathrm{~g}-\mathrm{O})$. Crossing northern Taiwan, the rainband forms along a near-surface convergence zone (green dotted curves, mostly $>5 \times 10^{-5} \mathrm{~s}^{-1}$ with confluence and acceleration) between the flow blocked and deflected northward by the topography of Taiwan and the unblocked flow farther to the north and west in the environment (but still ahead of the front, Fig. 9). Thus, in agreement with the observations, the effects of terrain (blocking) appeared to play a key role to initiate the rainband development, while the front helped provide and channel an enhanced background flow with its approach in the present case. Such a scenario is quite similar to those studied by Yeh and Chen (2002) and Wang et al. (2005). Thus, the frontal forcing, LLJ, terrain effects, and the BB process all work together to lead to the quasi-linear MCS and heavy rainfall in northern Taiwan in the present case. However, it is not possible to isolate and quantify their individual contribution here, and we do not intend to do so.

Figure 10 shows the development and evolution of convective cells over northern Taiwan and the upstream area in the model every $10 \mathrm{~min}$ during 19:20-22:10 UTC. In this quasistationary system (cf. Figs. 7d-f and 9), the BB process is successfully simulated by CReSS. For example, a new cell 

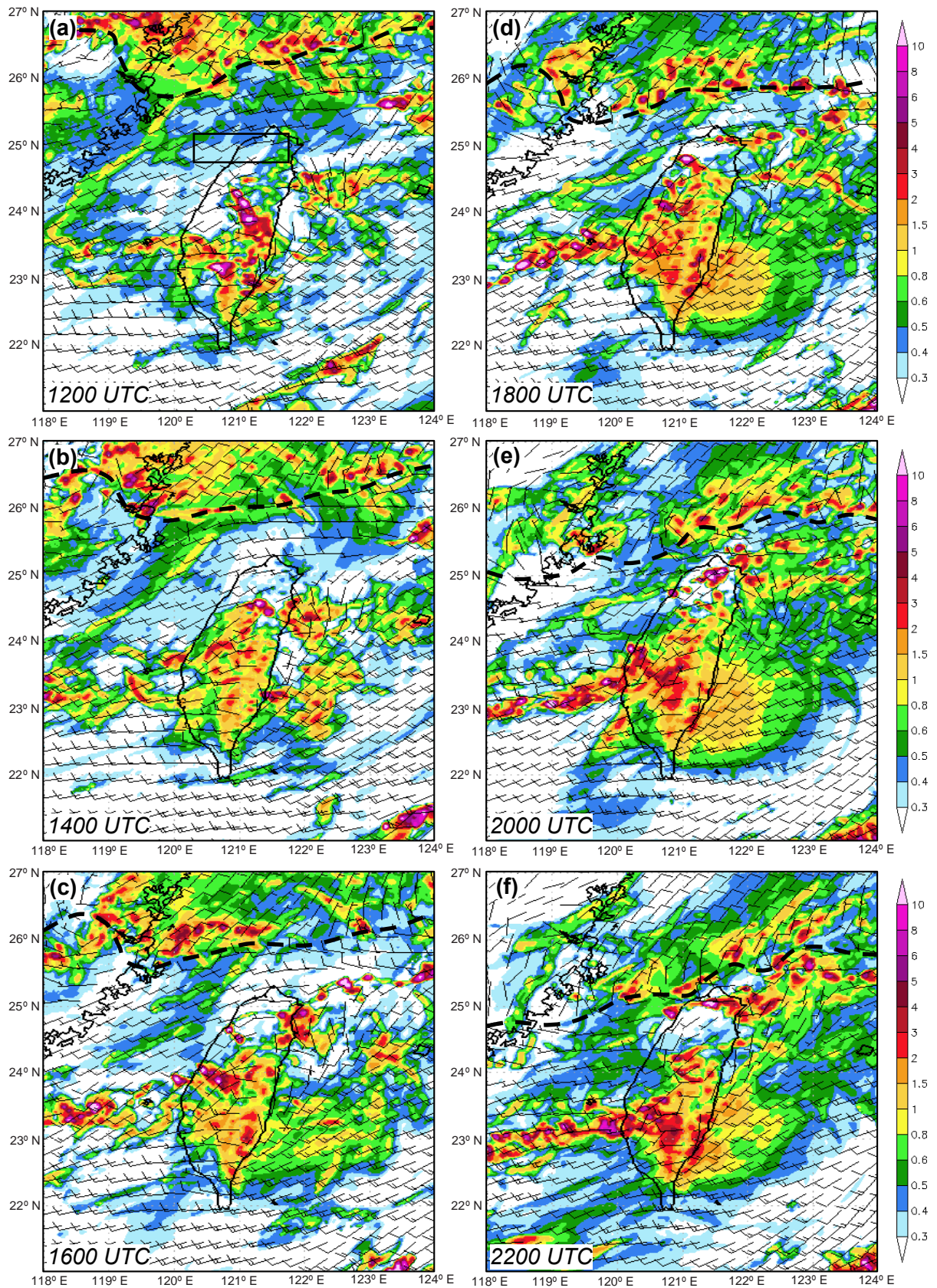

Figure 7. CReSS simulation of surface winds at $10 \mathrm{~m}$ height $\left(\mathrm{m} \mathrm{s}^{-1}\right)$ and column-maximum mixing ratio of precipitation (rain + snow + graupel, $\mathrm{g} \mathrm{kg}^{-1}$, shading, scale to the right) every $2 \mathrm{~h}$ from (a) 12:00 UTC to (f) 22:00 UTC on 11 June 2012. For winds, full (half) barbs denote $10(5) \mathrm{m} \mathrm{s}^{-1}$, and the surface frontal positions are marked (thick dashed lines). The rectangle in panel (a) depicts the area $\left(24.75-25.15^{\circ} \mathrm{N}, 120.35-121.75^{\circ} \mathrm{E}\right)$ used for the separation method.

labeled as "A2" develops about $20 \mathrm{~km}$ upstream from the old cell "A1" around 19:30 UTC and becomes mature near 20:10 UTC. Likewise, "B2" is triggered west of "B1" after 21:20 UTC and develops into a mature cell near 21:40 UTC and then the two cells merge near 21:50 UTC over northern Taiwan (Fig. 10, also cf. Fig. 9), in a way similar to that discussed by WKJ15. In the model, the training of multi- ple cells in succession clearly leads to heavy rainfall over the Taipei area (cf. Fig. 7e and f), in agreement with the observations. Therefore, even though the simulation of the first TL/AS MCS is less than ideal, the model results for the quasistationary BB lines (after about 18:00 UTC on 11 June) can be used to further investigate the BB process upstream from the old cells in this case. Thus, the area and time period se- 


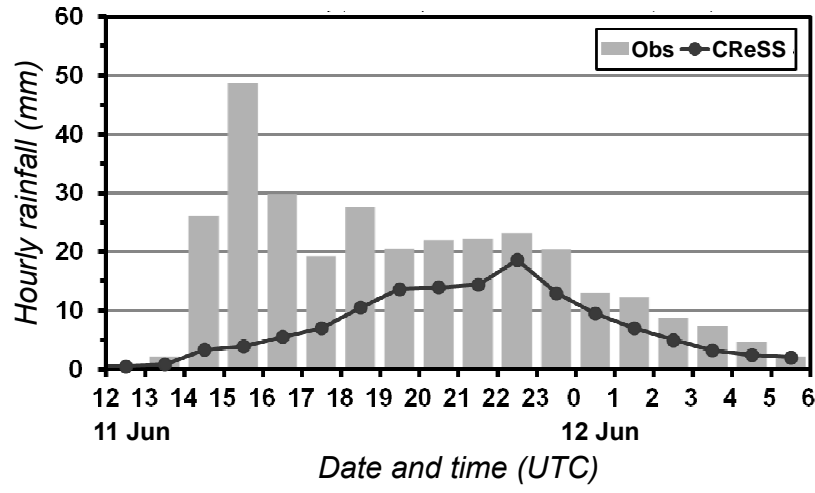

Figure 8. Time series of observed (gray bars) and simulated (curve with dots) hourly rainfall $(\mathrm{mm})$, averaged inside the box shown in Fig. $5 \mathrm{~b}\left(24.75-25.17^{\circ} \mathrm{N}, 120.87-121.85^{\circ} \mathrm{E}\right)$ over northern Taiwan from 12:00 UTC on 11 June to 06:00 UTC on 12 June 2012.

lected for the separation of $p_{0}$ and $p^{\prime}$, as described at the end of Sect. 2.3, are set to $24.75-25.15^{\circ} \mathrm{N}, 120.35-121.75^{\circ} \mathrm{E}$ (cf. Fig. 7a) and over 18:00-24:00 UTC on 11 June 2012.

\subsection{Structure of convective cells in the BB MCS}

In this subsection, the simulated structure of convective cells inside the BB system is first examined, before the discussion on the finer details of pressure perturbations and their associated effects in the BB process. The pair of old and new cells for study has been chosen to be B1 and B2 over the period of 20:00-21:40 UTC, as they are farther away and less affected by the terrain of northern Taiwan (cf. Fig. 10). To reveal the storm environment (provided by the background forcing), $\mathrm{E}-\mathrm{W}$ vertical cross sections along $25^{\circ} \mathrm{N}$ through the centers of both B1 and B2 (line AB in Fig. 10) are constructed and averaged over three outputs from 21:25 to 21:35 UTC, as shown in Fig. 11a. The equivalent potential temperature $\left(\theta_{\mathrm{e}}\right)$ has a minimum of about $350 \mathrm{~K}$ at mid-levels (near 4$5 \mathrm{~km}$ ) and increases both upward and downward in upstream as well as downstream regions, indicating the presence of convective (and conditional) instability (cf. Fig. 3). During the average period, the mean updraft of B1 is located near $121.35^{\circ} \mathrm{E}$ (cf. Fig. 10), and its immediate upstream region, i.e., where cell $\mathrm{B} 2$ is developing $\left(\sim 121.2^{\circ} \mathrm{E}\right)$, is characterized by strong near-surface convergence coupled with upperlevel divergence (Fig. 11a). Clearly favorable for new cell development upstream with near-surface convergence there, such a thermodynamic and kinematic structure under the influences of the front and terrain (as discussed in Sect. 4.2) is very similar to the composites of BB MCSs in the USA obtained by Schumacher and Johnson (2005, their Fig. 17b). The WSW-ENE cross section (along low-level flow) through B1 about 30 min earlier at 21:00 UTC shows a gradual acceleration of the upstream LLJ (thick arrow line) under the forcing of background convergence. As the jet approaches B1, which is already in mature stage (and quasi-steady), there is a rapid local acceleration then intense deceleration across $\mathrm{B} 1$, by about $10 \mathrm{~m} \mathrm{~s}^{-1}$ with a convergence in excess of $5 \times 10^{-3} \mathrm{~s}^{-1}$ (Fig. 11b). While this local acceleration is clearly a response to the development of $\mathrm{B} 1$, the resulting vertical wind shear from the south-southwest is strongest below $500 \mathrm{~m}$ under B1 and its immediate upstream, where a value of about 2-3 $\times 10^{-2} \mathrm{~s}^{-1}$ can be reached (Fig. 11c). The vertical wind shear upstream from B1 further aloft turns into northerly and then northeasterly at about $2 \mathrm{~km}$, as expected above the axis of the LLJ, but its value $\left(\sim 3 \times 10^{-3} \mathrm{~s}^{-1}\right)$ is 1 order of magnitude smaller (Fig. 11c). Thus, the vertical wind shear in the storm environment of B1 (and B2) is strongest near the surface. Also, the deep convection can be seen to tilt eastward with height in both cross sections, consistent with the direction of the upper-level winds and the evolution of stratiform area (cf. Figs. 3 and 4).

In Fig. 12, the perturbations in $\theta$ (i.e., $\theta^{\prime}$ ) and horizontal winds $\left(u^{\prime}\right.$ and $\left.v^{\prime}\right)$ obtained through the separation method (cf. Sect. 2.3), as well as the associated convergence and divergence, surrounding the pair of cells B1 and B2 at the surface between 20:00 and 21:00 UTC are presented every 20 min. During this initiation period of B2, while there exists positive $\theta^{\prime}$ (of $0.4-0.8 \mathrm{~K}$ ) below the updraft of B1, its induced cold pool is very weak at the surface, with a $\theta^{\prime}$ of only $-0.3 \mathrm{~K}$ at most, and is roughly $10 \mathrm{~km}$ to the east at the forward flank (Fig. 12). The convergence at the leading edge of the diverging, marginally colder air (denoted by dotted curves) extends to the southeast and south of B1 at 20:0020:20 UTC (Fig. 12a and b) but gradually moves to the east afterwards (Fig. 12c and d). At the rear side of B1, the new cell B2 (marked by a blue " $x$ ") develops inside a region of surface convergence, consistent with Fig. 9d, e, and f, and quite far (at least $10 \mathrm{~km}$ ) from both the weak cold pool and the leading edge of its outflow (Fig. 12). Therefore, the cold pool does not play any significant role in the initiation of the back-building cell B2 in the model, and the B1-B2 pair appears to be ideal for further investigation in greater detail.

The results of $\nabla^{2} p^{\prime}$ obtained by the two different methods (by separation and from Eqs. 3 and 4) as described in Sect. 2.3 at two different heights near 0.8 and $3 \mathrm{~km}$ are compared in Fig. 13, also for 21:00 UTC as an example. In general, the patterns are very similar. At $0.8 \mathrm{~km}$, negative $\nabla^{2} p^{\prime}$ (implying $p^{\prime}>0$ ) occurs near the updraft of B1 with positive $\nabla^{2} p^{\prime}$ (implying $p^{\prime}<0$ ) to the east near the downdraft (Fig. 13a and b). West of B1, where B2 is developing, positive (negative) $\nabla^{2} p^{\prime}$ is found to the south (north) of the nearsurface convergence zone. Near $3 \mathrm{~km}$, the updraft of B1 corresponds to $\nabla^{2} p^{\prime}>0$ and $\nabla^{2} p^{\prime}<0$ occurs to its western flank and further upstream over B2 (Fig. 13d and e). The Laplacian of buoyancy pressure perturbation $\left(\nabla^{2} p_{\mathrm{b}}^{\prime}\right)$ alone computed from Eq. (3) closely resembles that of the total pressure perturbations at both levels (except perhaps a slight southward shift near the updraft of B1 at $0.8 \mathrm{~km}$ ), implying a dominant role of $p_{\mathrm{b}}^{\prime}$ over $p_{\mathrm{d}}^{\prime}$ in this event. Nevertheless, Fig. 13 confirms that the two methods yield consistent results. 

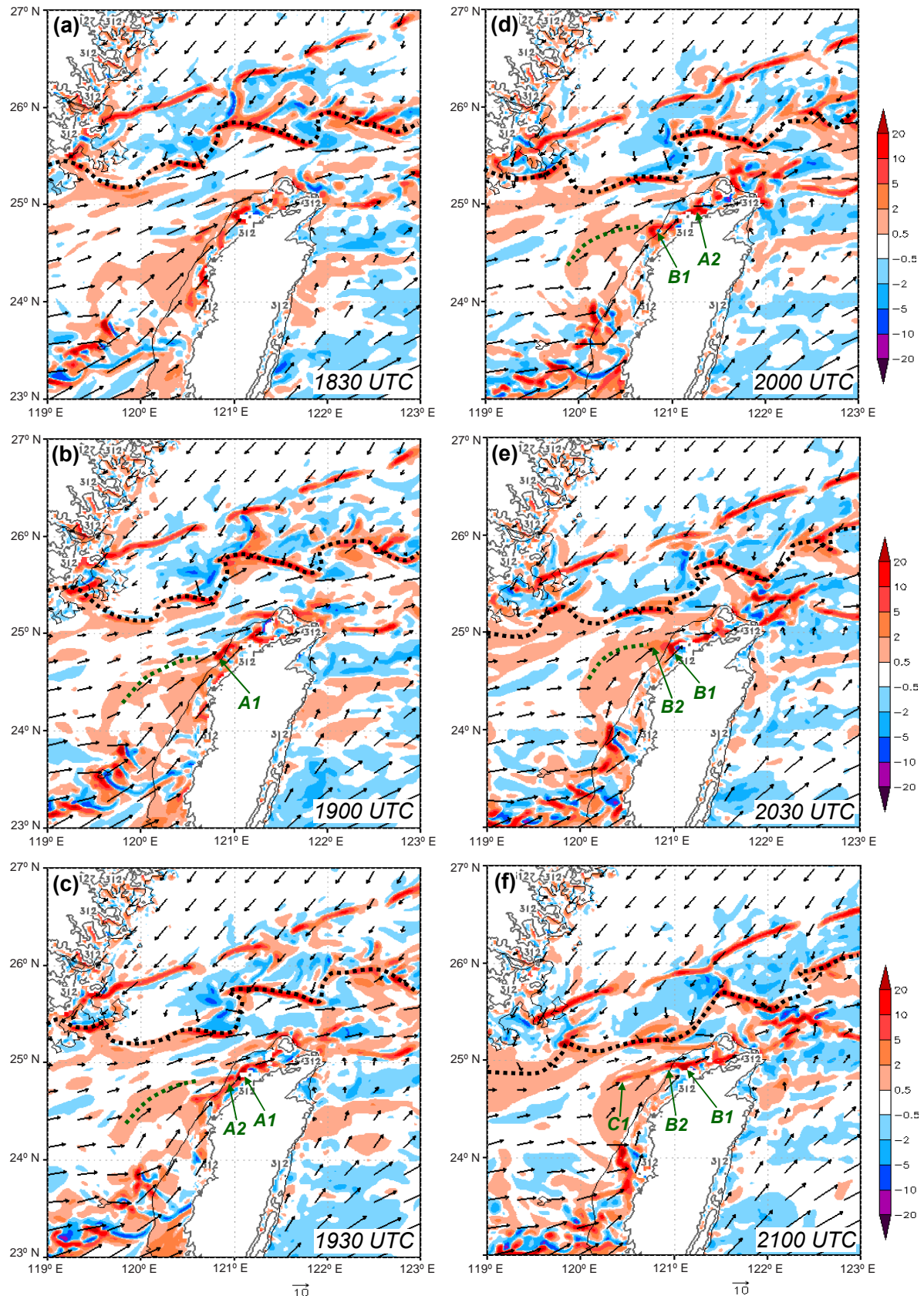

Figure 9. CReSS simulation of horizontal winds ( $\mathrm{m} \mathrm{s}^{-1}$, vectors, reference length at bottom) and convergence/divergence $\left(10^{-4} \mathrm{~s}^{-1}\right.$, shading, scale to the right, positive for convergence) at $312 \mathrm{~m}$ height (contoured in thick gray) every $30 \mathrm{~min}$ from (a) 18:30 UTC to (f) 21:00 UTC on 11 June 2012. The frontal positions (black dotted lines) and convergence axis (green dotted lines) and convective cells of interests are marked.

\subsection{Analysis of pressure perturbations}

To examine the distributions of pressure perturbations and their roles in the BB process in greater detail, a series of vertical cross sections through the updraft center of B1 at $5 \mathrm{~km}$ and the near-surface center of B2 from 20:00 to 21:00 UTC (each roughly $50 \mathrm{~km}$ in length, cf. Figs. 10 and 12), i.e., dur- ing the initiation stage of B2, are constructed. Here, the structures of $\nabla^{2} p^{\prime}$ are first presented, so as to better infer to the patterns of $p^{\prime}$ discussed later through Eqs. (3) and (4). At 20:00 UTC when signs of B2 are yet to appear (Fig. 14a), the updraft of B1 $\left(>5 \mathrm{~m} \mathrm{~s}^{-1}\right)$ is more upright with downdrafts at both flanks ( $>1 \mathrm{~m} \mathrm{~s}^{-1}$ at mid-level or above). At the backside (upstream) of the updraft, in particular, $\nabla^{2} p^{\prime}$ is positive at 


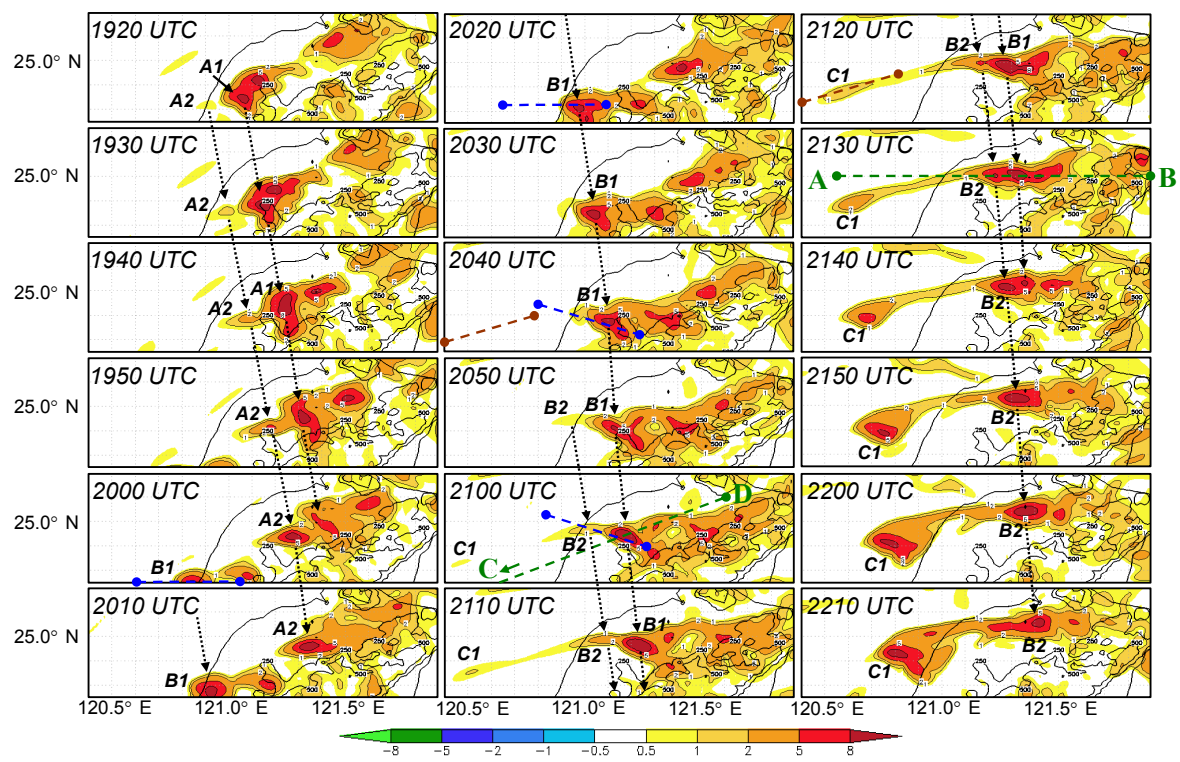

Figure 10. Model-simulated column-maximum vertical velocity ( $w, \mathrm{~m} \mathrm{~s}^{-1}$, color and thin contours) every 10 min during 19:20-22:10 UTC on 11 June 2012, overlaid with terrain elevation (m, thick contours at 250 and $500 \mathrm{~m}$ ) in northern Taiwan. The color scale is shown at the bottom, and the contour at $0.5 \mathrm{~m} \mathrm{~s}^{-1}$ is not drawn. Old cells (A1, B1, and C1) and nearby new cells (A2, B2) of interests are labeled. Green dashed lines $\mathrm{AB}$ and $\mathrm{CD}$ depict the vertical cross sections used in Fig. 11, and the short segments depict those used in Figs. 14-18 (blue (brown) ones through B1 (C1)).
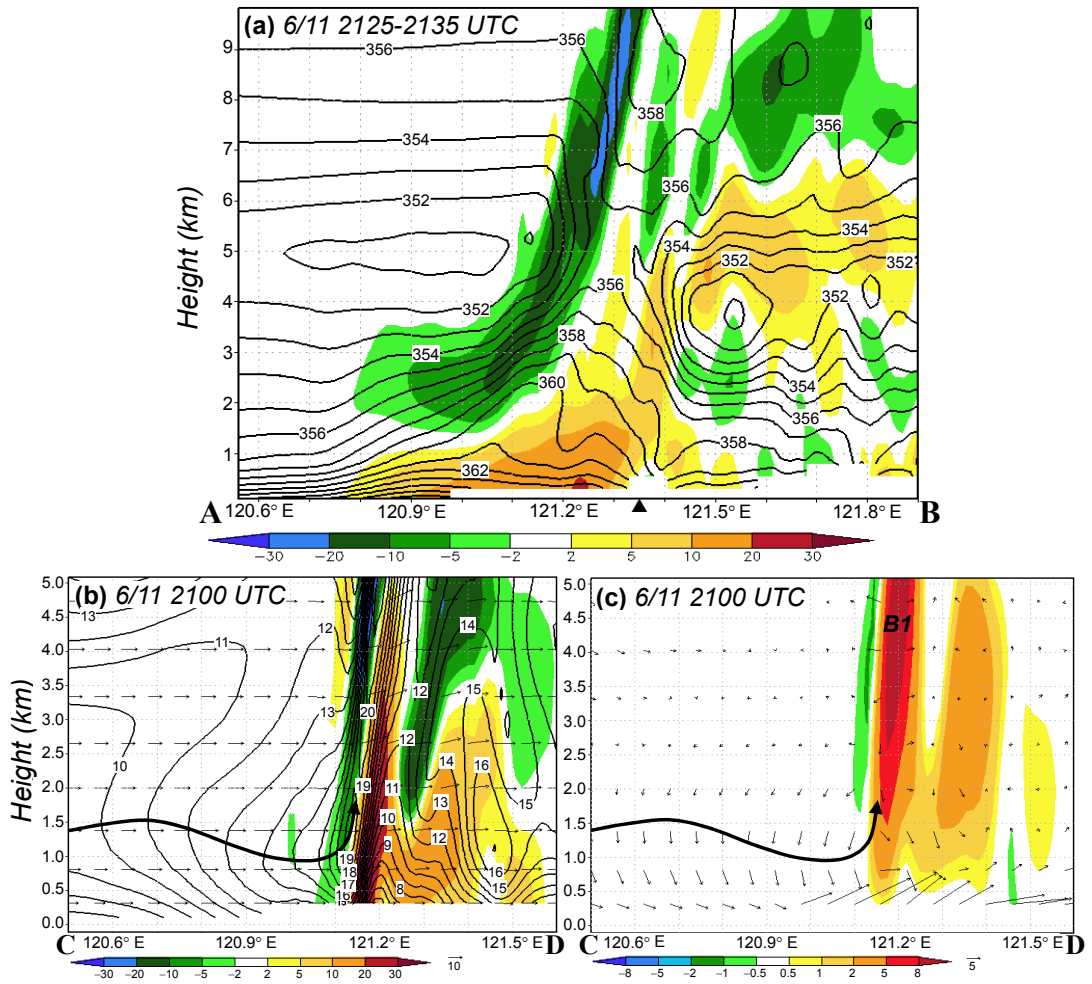

Figure 11. (a) E-W vertical cross section of model-simulated convergence/divergence $\left(10^{-4} \mathrm{~s}^{-1}\right.$, color, positive for convergence) and $\theta_{\mathrm{e}}(\mathrm{K}$, contour, every $1 \mathrm{~K}$ ) along $25^{\circ} \mathrm{N}$ (line AB in Fig. 10), averaged over 21:25-21:35 UTC on 11 June 2012. The triangle marks the mean location of the updraft of B1. (b, c) As in panel (a), except showing (b) convergence/divergence (color) and wind vectors ( $\mathrm{m} \mathrm{s}^{-1}$ ) and speed (isotach every $\left.1 \mathrm{~m} \mathrm{~s}^{-1}\right)$ and (c) $w\left(\mathrm{~m} \mathrm{~s}^{-1}\right.$, color) and vertical wind shear vector $\left(10^{-3} \mathrm{~s}^{-1}\right.$, in cardinal direction, reference vectors both plotted) along the WSW-ENE section (line CD in Fig. 10) at 21:00 UTC on 11 June 2012. Thick arrow-lines in panels (b, c) depict the axis of the LLJ. 


\section{(a) 2000 UTC}

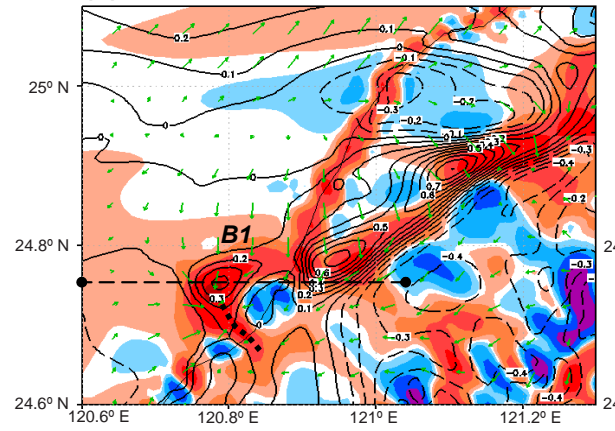

(b) 2020 UTC

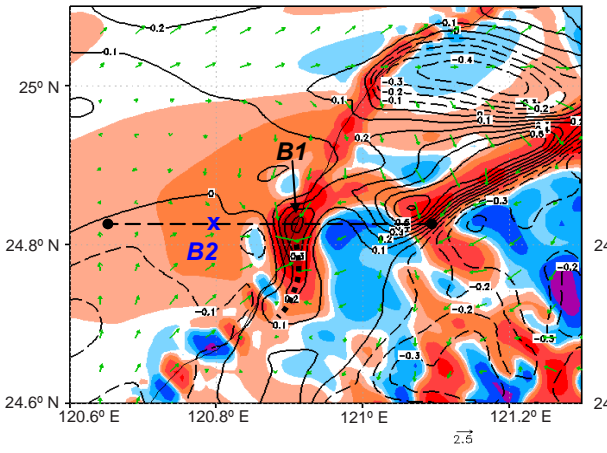

(c) 2040 UTC

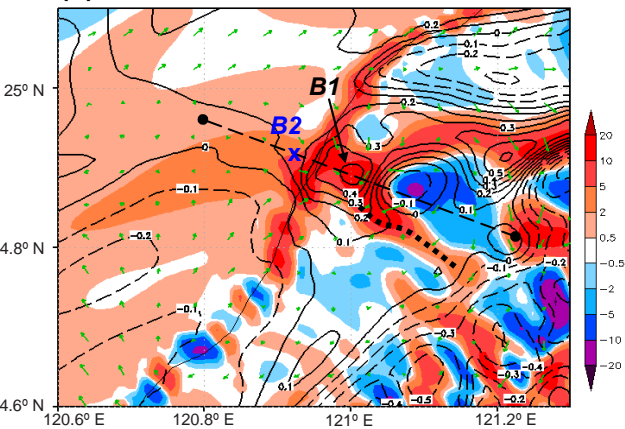

(d) 2100 UTC

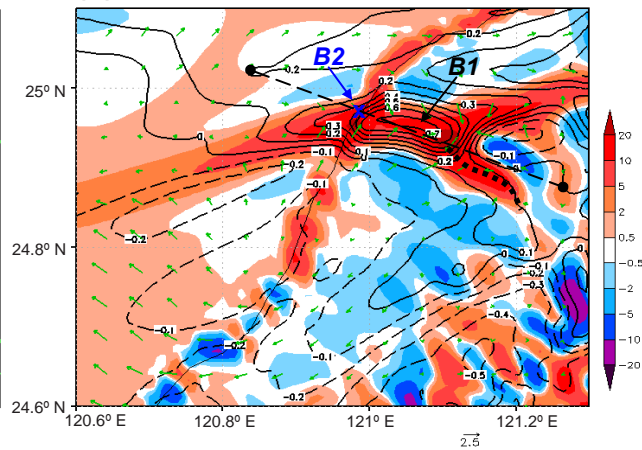

Figure 12. CReSS simulation of convergence/divergence $\left(10^{-4} \mathrm{~s}^{-1}\right.$, shading, scale to the right, positive for convergence), $10 \mathrm{~m}$ wind perturbation ( $\mathrm{m} \mathrm{s}^{-1}$, green vectors, reference length at bottom), and potential temperature perturbation $\left(\theta^{\prime}\right.$, $\mathrm{K}$, contours every $0.1 \mathrm{~K}$, dashed for negative values) at the surface every $20 \mathrm{~min}$ from (a) 20:00 UTC to (f) 21:00 UTC, 11 June 2012. Cells B1 (black) and B2 (blue), axis of convergence (thick dotted line) produced by downdraft outflow of B1, and locations of vertical cross sections as in Fig. 10 (straight dashed lines) are marked.

mid-level and negative both above and below, corresponding to $p^{\prime}<0$ and $p^{\prime}>0$, respectively (as labeled by " $\mathrm{L}$ " and " $\mathrm{H}$ "). Again, the pattern of $\nabla^{2} p^{\prime}$ is largely attributable to its buoyant $\left(\nabla^{2} p_{\mathrm{b}}^{\prime}\right)$ instead of dynamical component $\left(\nabla^{2} p_{\mathrm{d}}^{\prime}\right.$, Fig. $14 \mathrm{~b}$ and c). Twenty minutes later at 20:20 UTC (Fig. 14d), the updraft of B1 strengthens to more than $8 \mathrm{~m} \mathrm{~s}^{-1}$ and becomes more tilted, but the basic pattern of $\nabla^{2} p^{\prime}$ at its western flank and the upstream region remains. At this time, the suppressing downdraft there weakens, and B2 is developing $\left(\sim 0.5 \mathrm{~m} \mathrm{~s}^{-1}\right)$ just west of the sinking motion and about $15 \mathrm{~km}$ upstream from the core of B1. This new development is associated with $p^{\prime}<0$ below $1 \mathrm{~km}$ and $p^{\prime}>0$ over $1-3 \mathrm{~km}$, and the perturbations (and those of B1) are also mainly from the buoyant rather than dynamical effects (Fig. 14e and f).

At 20:40 UTC (Fig. 14g), B1 further strengthens and is even more tilted with height, and its associated downdraft below the mid-level $\left(>2 \mathrm{~m} \mathrm{~s}^{-1}\right.$ near $\left.4 \mathrm{~km}\right)$ now appears only at the eastern (downwind) side (cf. Fig. 12c). The upward motion of B2 can now reach over $1 \mathrm{~m} \mathrm{~s}^{-1}$ and extend further upstream, while a layer of positive $\nabla^{2} p^{\prime}$ (implying $p^{\prime}<0$ ) forms near $5 \mathrm{~km}$, again mainly from the buoyant effects (cf. Fig. 14h). The distribution of $\nabla^{2} p_{\mathrm{d}}^{\prime}$ is only significant at both flanks of the updraft of B1 below about $3.5 \mathrm{~km}$ (and at its eastern flank near $5 \mathrm{~km}$, Fig. 14i), which forms gradually as
B1 intensifies (Fig. 14c and f). The configuration of positive (negative) $p_{\mathrm{d}}^{\prime}$ at the rear (forward) flank of the updraft near $500 \mathrm{~mm}$ (below the jet level, cf. Fig. 11c) and a reversed pattern above (near $2-3 \mathrm{~km}$ ) is consistent with the shearing (plus extension) effect (cf. Eq. 4), in agreement with WKJ15 and other earlier studies. However, since $w$ and its horizontal gradient are weak near the surface, where the vertical wind shear is larger (also Fig. 11c), the value of $\nabla^{2} p_{\mathrm{d}}^{\prime}$ is smaller than that in WKJ15. Also, due to the farther distance, a direct role played by the dynamical pressure perturbations in new cell initiation of B2 appears limited in the present case here.

Both B1 and B2 intensify at 21:00 UTC, and the latter, peaking at about $1.5 \mathrm{~m} \mathrm{~s}^{-1}$, can now reach $4 \mathrm{~km}$ while the layer of $\nabla^{2} p^{\prime}>0$ above (near $5 \mathrm{~km}$ ) also grows stronger (Fig. 14j). A downdraft at the rear flank of $\mathrm{B} 1$ reappears at mid-levels and penetrates down to $3 \mathrm{~km}$ at this time, acting to separate B2 from B1 (also Fig. 13d). Like earlier times since 20:20 UTC, the total pattern of $\nabla^{2} p$ is dominated by $\nabla^{2} p_{\mathrm{b}}^{\prime}$ everywhere, except near the base of B1 (below $1.5 \mathrm{~km}$ ) where $\nabla^{2} p_{\mathrm{d}}^{\prime}$ contributes significantly (Fig. 14k and l). Thus, the buoyancy-related effect is consistently the more dominant one in the region of $\mathrm{B} 2$ during its initiation stage in the model, suggesting the importance of near-surface conver- 

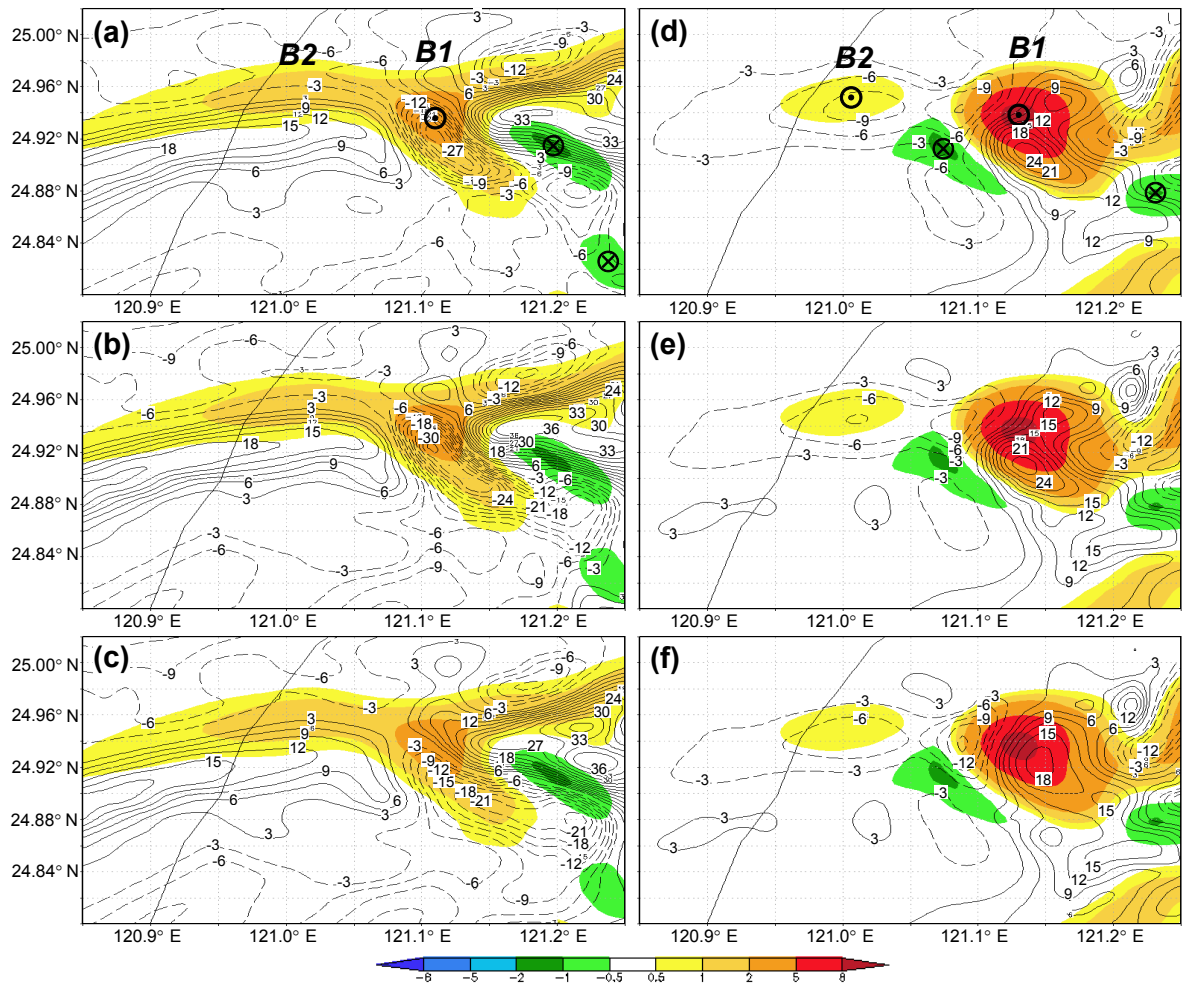

Figure 13. Model-simulated $w\left(\mathrm{~m} \mathrm{~s}^{-1}\right.$, color, scale at bottom) and Laplacian of perturbation pressure $\left(10^{-6} \mathrm{~Pa} \mathrm{~m}^{-2}\right.$, contour, every $3 \times$ $10^{-6} \mathrm{~Pa} \mathrm{~m}^{-2}$, dashed for negative values) of cells B1 and B2 at (left) $806 \mathrm{~m}$ and (right) $2929 \mathrm{~m}$ at 21:00 UTC on 11 June 2012 . (a, d) $\nabla^{2} p^{\prime}$ obtained from separation method; (b, e) $\nabla^{2} p^{\prime}=\nabla^{2} p_{\mathrm{b}}^{\prime}+\nabla^{2} p_{\mathrm{d}}^{\prime}$ and (c,f) $\nabla^{2} p_{\mathrm{b}}^{\prime}$ computed from Eqs. (3) and (4). Cells B1 and B2 and updraft and downdraft centers are labeled in panels (a) and (d).

gence in driving the development of the line-shaped MCS in this event, as also shown earlier in Sect. 4.2 (and cf. Fig. 11a).

Nevertheless, the propagation speed of B1 is indeed slower than B2 in Fig. 10 and can be estimated to be about $8.9 \mathrm{~m} \mathrm{~s}^{-1}$ near 21:00 UTC. Caused by the dynamical effect of $p_{\mathrm{d}}^{\prime}$, this slowdown implies an increase in low-level blocking and subsequent upstream convergence by about $1 \times 10^{-4} \mathrm{~s}^{-1}$ using Fig. $11 \mathrm{~b}$ (with a LLJ of $12.5 \mathrm{~m} \mathrm{~s}^{-1}$ near $40 \mathrm{~km}$ upstream), or $2.2 \times 10^{-4} \mathrm{~s}^{-1}$ larger than its surrounding with a background speed divergence of $\sim 1.2 \times 10^{-4} \mathrm{~s}^{-1}$ following WKJ15 (p. 11109). Since this is no more than $20 \%$ of the maximum convergence near B2 and its immediate upstream (west of $121.2^{\circ} \mathrm{E}$, cf. Fig. 11a), the minor role of $p_{\mathrm{d}}^{\prime}$ in the initiation of B2 in the present case can be confirmed.

The buoyancy $B$ (or more precisely, the vertical buoyant force per unit mass) in Eq. (1) and its contributing terms as given in Eq. (2) on the same vertical cross sections are shown in Fig. 15. At 20:00 UTC, as expected, $B$ is positive inside the cumulonimbus B1 and negative in the top portion of the cloud $(>6.5 \mathrm{~km})$ and below the main updraft $(<2 \mathrm{~km}$, Fig. 15a). Such a pattern is due to the combined effects of positive virtual potential temperature perturbation $\left(\theta_{\mathrm{v}}^{\prime}>0\right)$ clearly from latent heat release (LHR) inside the cloud and the downward drag by all hydrometeors (includ- ing both cloud particles and precipitation) maximized below the updraft core (Fig. 15b and c). In the downdrafts at the flanks (which originate from higher levels), $B$ and $g\left(\theta_{\mathrm{v}}^{\prime} / \theta_{\mathrm{v} 0}\right)$ are also mostly positive from adiabatic warming outside the cloud.

From 20:20 to 21:00 UTC when the updraft of B1 becomes increasingly tilted, the buoyancy $B$ in the core region of the updraft remains positive because of LHR, as the drag force shifts toward the downwind side (Fig. 15d-1). Below and east of the updraft, $B$ is strongly negative near the surface due to the drag and a rapid reduction in positive $\theta_{\mathrm{v}}^{\prime}$ as the air descends. Even though this reduction in $\theta_{\mathrm{v}}^{\prime}$ suggests some evaporative cooling, the cold pool (and surface outflow) would be to the east of B1, as confirmed in Fig. 12. On the upstream side where B2 is developing, $B>0$ appears near the surface with $B<0$ further aloft at $2-5 \mathrm{~km}$ (Fig. $15 \mathrm{~d}$, g, and j) and can be attributed, respectively, to LHR and adiabatic cooling associated with ascending motion (Fig. 15e, h, and k) in a convectively unstable environment. Apparently, as B2 develops, the cooling above it and to the west (roughly $120.8-121^{\circ} \mathrm{E}$ ) leads to a layer of positive $\partial B / \partial z$ and $\nabla^{2} p_{\mathrm{b}}^{\prime}$ near $5 \mathrm{~km}$ (cf. Eq. 3), since the air further above is stable (cf. Fig. 11a). In Fig. 15, however, one particular center of negative $B$, near $120.85^{\circ} \mathrm{E}$ and $3 \mathrm{~km}$ at 20:20 UTC, develops in a sinking area 

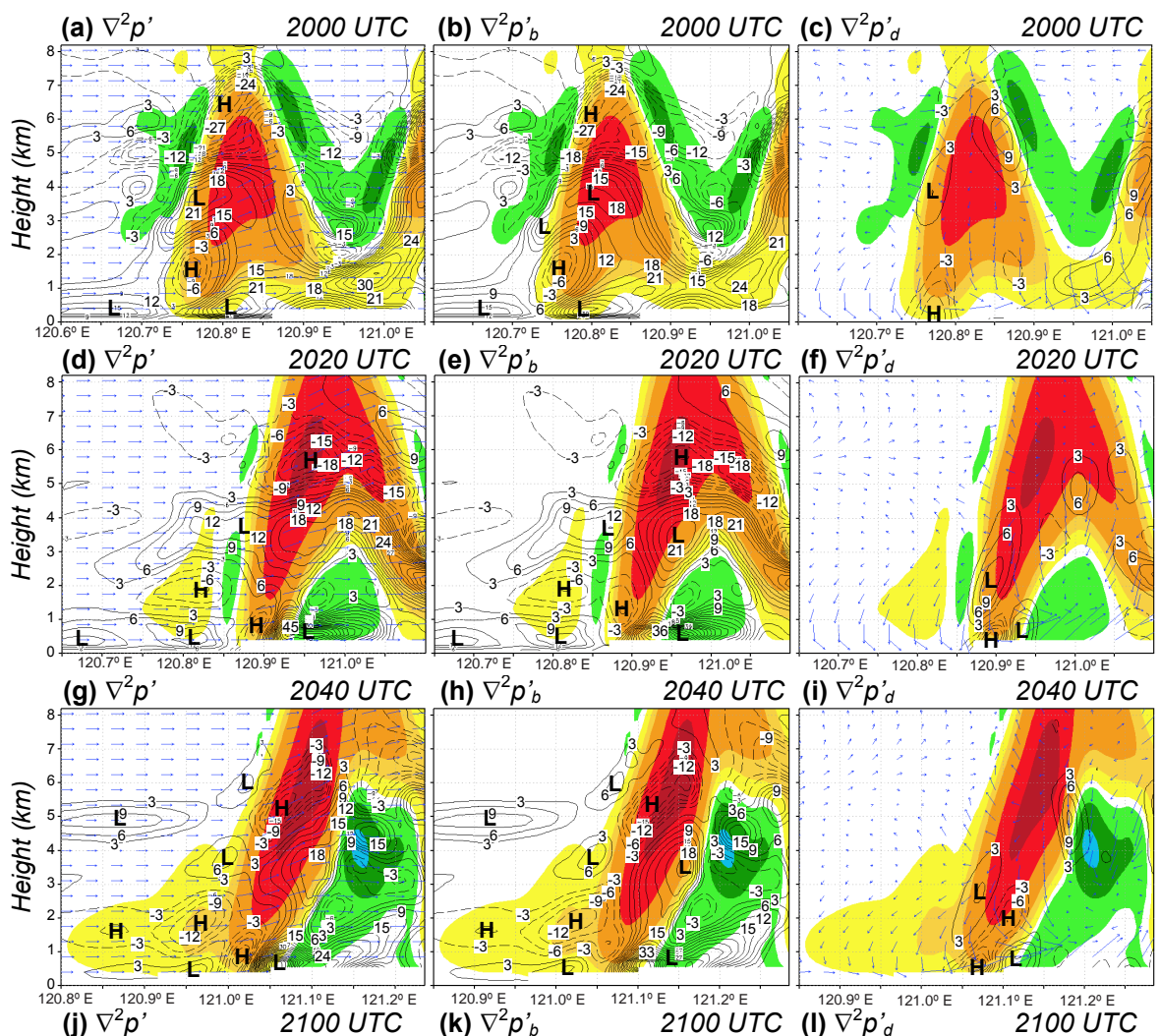

(h) $\nabla^{2} p_{b}^{\prime}$ 2040 UTC (i) $\nabla^{2} p_{d}^{\prime}$
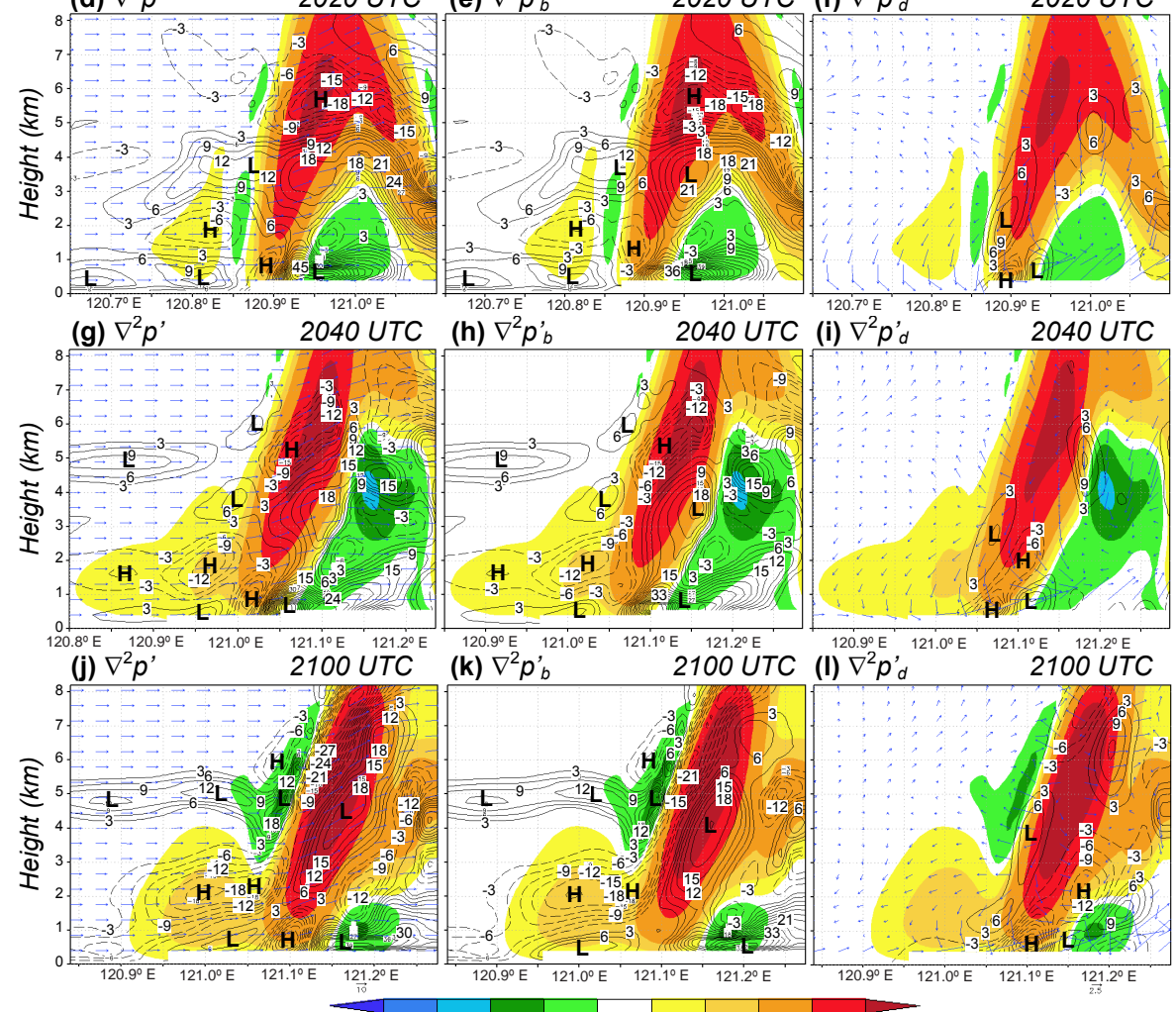

(k) $\nabla^{2} p_{b}^{\prime}$

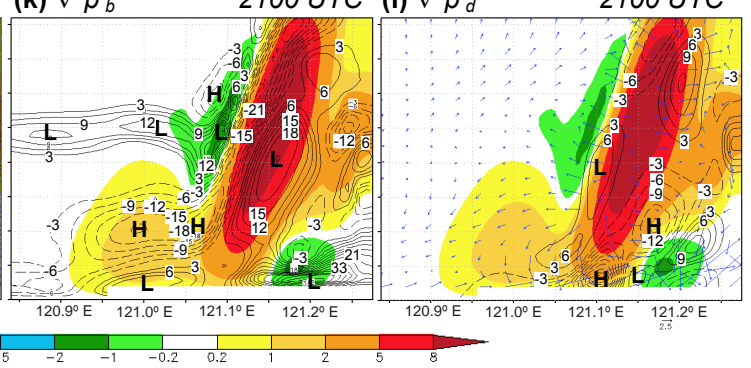

Figure 14. Vertical cross sections of model-simulated $w\left(\mathrm{~m} \mathrm{~s}^{-1}\right.$, color) and (a) $\nabla^{2} p^{\prime}\left(10^{-6} \mathrm{~Pa} \mathrm{~m}^{-2}\right)$ and wind vectors $\left(\mathrm{m} \mathrm{s}^{-1}\right.$, reference vector at bottom) on section plain, (b) $\nabla^{2} p_{\mathrm{b}}^{\prime}$ (computed from Eq. 3), and (c) $\nabla^{2} p_{\mathrm{d}}^{\prime}$ (computed from Eq. 4) and vertical wind shear vector $\left(10^{-3} \mathrm{~s}^{-1}\right.$, in cardinal direction, reference vector at bottom) along the E-W segment through B1 and B2 at 20:00 UTC on 11 June 2012 (cf. Fig. 10). All contour intervals are $3 \times 10^{-6} \mathrm{~Pa} \mathrm{~m}^{-2}$ (zero line omitted, dashed for negative values), and letters $\mathrm{H}$ (L) denote corresponding high (low) pressure perturbations. (d-f, $\mathbf{g - i} \mathbf{i}, \mathbf{j}-\mathbf{l})$ As in panels (a-c), except at 20:20, 20:40, and 21:00 UTC (WNW-ESE segments for 20:40 and 21:00 UTC, cf. Fig. 10), respectively.

at the western edge of the cumulus and therefore is also enhanced by evaporative cooling of cloud droplets (Fig. 15d-l). Thus, the cooling and subsequently $B<0$ (near $3 \mathrm{~km}$ ) associated with B2 is not only by the adiabatic effect but also by evaporation at an earlier stage of initiation, for example around 20:20 UTC (Fig. 15d and e). However, at later times when the updraft of B1 becomes more tilted and B2 grows higher and stronger, it becomes more difficult for the rearflank downdraft to reach close to the surface (cf. Fig. 15j-1), even though its strength can be sensitive to the cloud microphysical scheme (e.g., Morrison et al., 2009).

Upstream from B1, the near-surface warming and cooling above, with maxima near 1 and $3-4 \mathrm{~km}$, respectively, create a decrease in buoyancy with height $(\partial B / \partial z<0)$ that grows stronger with time near B2 (Fig. 15d, g, and j). Together with the (near) exponential decrease of $\rho_{0}$ upward, this condition leads to $\nabla^{2} p_{\mathrm{b}}^{\prime}<0$ in Eq. (3), and thus $p_{\mathrm{b}}^{\prime}>0$ that peaks slightly above $1 \mathrm{~km}$ and intensifies through time, as obtained using the relaxation method (Sect. 2.3) and shown in Fig. 16 

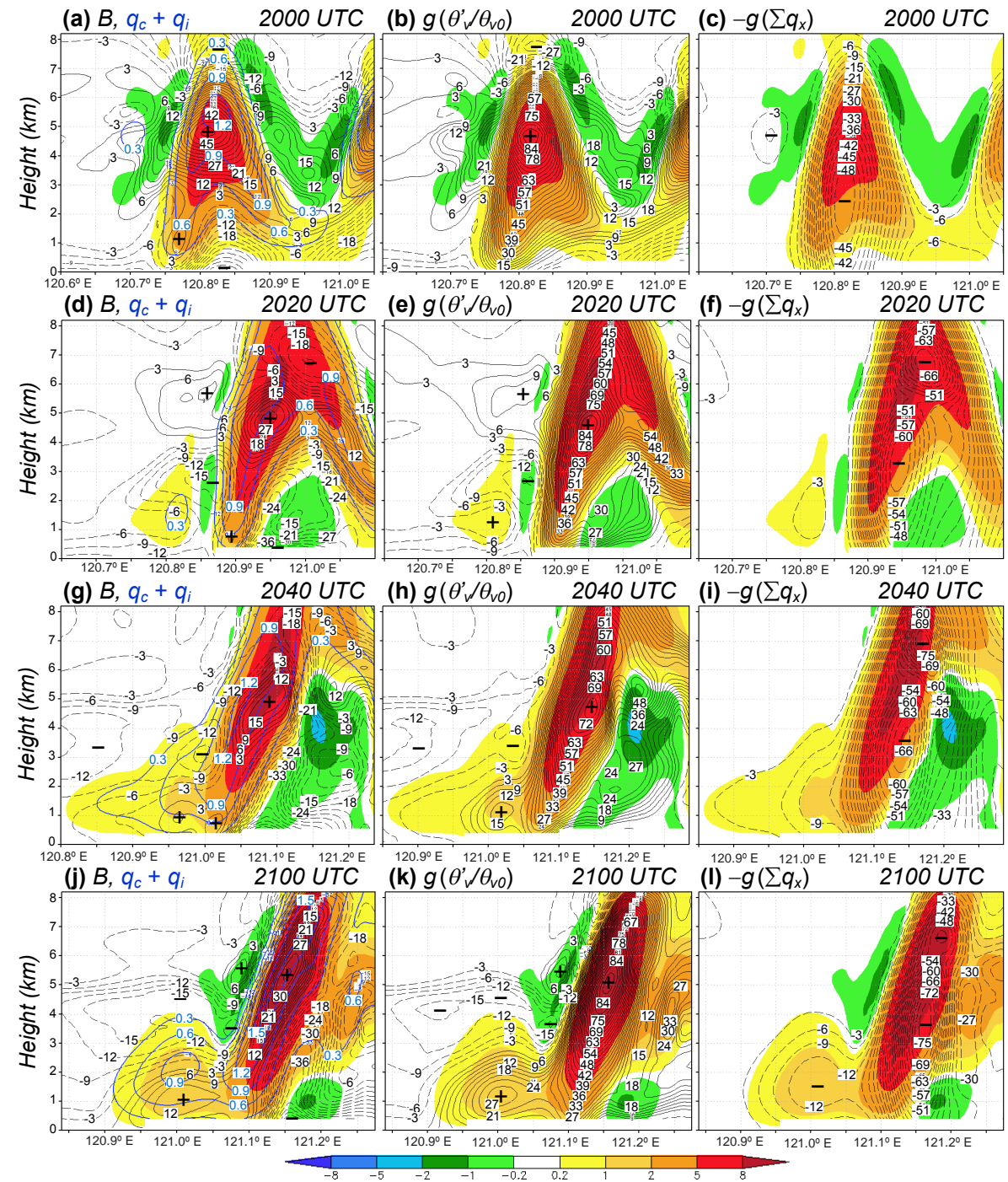

Figure 15. (a-c) As in Fig. 14a-c, but showing $w$ and (a) buoyancy $B\left(10^{-3} \mathrm{~m} \mathrm{~s}^{-2}\right.$, black contour) and mixing ratio of cloud particles $\left(\mathrm{g} \mathrm{kg}^{-1}\right.$, blue contour, every $\left.3 \mathrm{~g} \mathrm{~kg}^{-1}\right)$, (b) $g\left(\theta_{\mathrm{v}}^{\prime} / \theta_{\mathrm{v} 0}\right)\left(10^{-3} \mathrm{~m} \mathrm{~s}^{-2}\right)$, and (c) $-g \sum q_{x}\left(10^{-3} \mathrm{~m} \mathrm{~s}^{-2}\right)$. All black contour intervals are $3 \times$ $10^{-6} \mathrm{~Pa} \mathrm{~m}^{-2}$ (dashed for negative values, zero line omitted), and $+(-)$ signs denote upward (downward) maxima. (d-f, $\left.\mathbf{g}-\mathbf{i}, \mathbf{j}-\mathbf{l}\right)$ As in panels (a-c), except at 20:20, 20:40, and 21:00 UTC, respectively.

(middle column). The upward decrease of $p_{\mathrm{b}}^{\prime}$, as the major component of total $p^{\prime}$, in turn produces an upward-directed buoyant PGF to help B2 develop further (Fig. 16, left and middle columns). Thus, the combined effect of buoyancy $B$ (cf. Fig. 15, left column) and total perturbation PGF in the vertical (cf. Eq. 1) is upward acceleration of parcels in B2 (Fig. 16, right column) to eventually reach free ascent and ignite deep convection (near 21:20 UTC, cf. Fig. 10).

\section{Discussion}

In the previous section, the pressure perturbation and buoyancy, dominated by the thermodynamic effects (including both adiabatic and diabatic ones from condensation or evap- oration), as well as the resultant upward development at the initiation stage of cell B2 are examined (Figs. 13-16). The specific roles played by the old cell $\mathrm{B} 1$ in triggering $\mathrm{B} 2$, however, are still not fully clear. Therefore, we further compare the initiation of an isolated cell farther upstream, C1, where no existing cell is present nearby (cf. Figs. 9f and 10), with B1-B2 pair and discuss their differences. Obviously, cells like $\mathrm{C} 1$ can also develop on their own under the background forcing (cf. Fig. 9), as also seen in Fig. 6, but a comparison allows us to identify the additional role of B1 to new cell triggering and thus to the BB process about $15-30 \mathrm{~km}$ upstream of the old cell in the present case.

Figure 17 shows similar plots as in Fig. 14 but through cell $\mathrm{C} 1$ on cross sections along the low-level convergence 

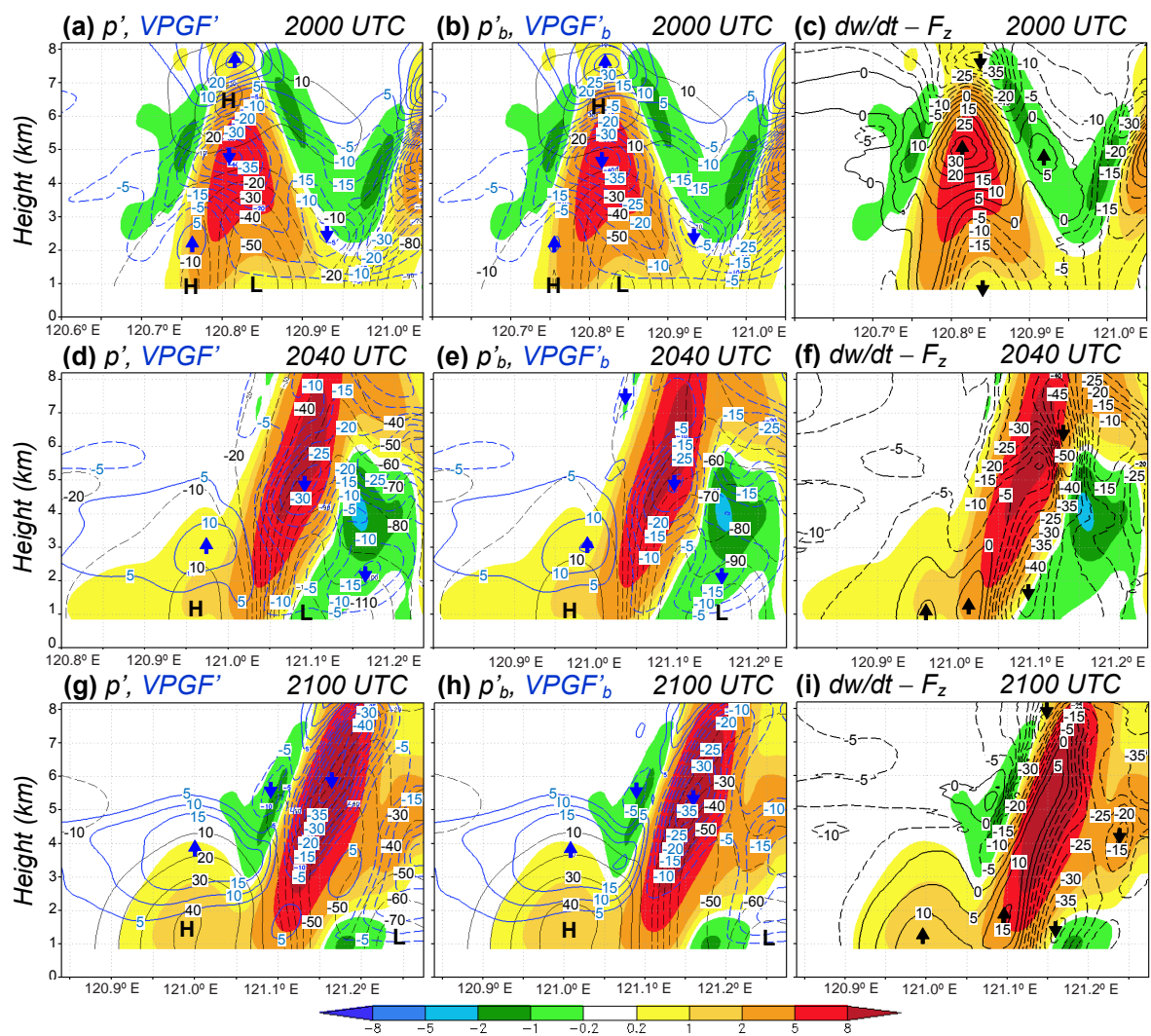

Figure 16. As in Fig. 14, but showing $w$ and (a, d, g) $p^{\prime}=p_{\mathrm{b}}^{\prime}+p_{\mathrm{d}}^{\prime}(\mathrm{Pa}$, black contour, every $10 \mathrm{~Pa}$, dashed for negative values) obtained from the relaxation method and the corresponding perturbation PGF in the vertical $\left(-\left(\partial p^{\prime} / \partial z\right) / \rho_{0}, 10^{-3} \mathrm{~m} \mathrm{~s}^{-2}\right.$, blue contour), (b, e, h) $p_{\mathrm{b}}^{\prime}$ (Pa) and its vertical PGF $\left(10^{-3} \mathrm{~m} \mathrm{~s}^{-2}\right)$, and $(\mathbf{c}, \mathbf{f}, \mathbf{i}) \mathrm{d} w / \mathrm{d} t$ from vertical perturbation PGF and $B\left(10^{-3} \mathrm{~m} \mathrm{~s}^{-2}\right.$, black contour). For force (per unit mass) and acceleration, all contour intervals are $5 \times 10^{-3} \mathrm{~m} \mathrm{~s}^{-2}$ (dashed for negative values), and upward (downward) arrows denote maxima (minima).

zone (WSW-ENE oriented) at 20:40 and 21:20 UTC, at the beginning of the initiation and right before the break out of deep convection, respectively (cf. Fig. 10). At 20:40 UTC (Fig. 17a), C1 is located near the left edge of the plots, while B2 appears near the right edge. At this early stage, the weak rising motion is associated with $\nabla^{2} p^{\prime}>0$ (or $p^{\prime}<0$ ) below about $1 \mathrm{~km}$ and $\nabla^{2} p^{\prime}<0$ (or $p^{\prime}>0$ ) slightly above near 1$2.5 \mathrm{~km}$, again mostly from the buoyant component (Fig. 17ac). This pattern is because $B$ is maximized near $1 \mathrm{~km}$ even though its value is negative $(B<0)$ everywhere (not shown), indicating that the near-surface atmosphere is still stable and the positive $w$ is forced by the convergence at this time.

At 21:20 UTC when C1 grows much stronger $\left(\sim 1.5 \mathrm{~m} \mathrm{~s}^{-1}\right)$, the same pattern continues to amplify and extends upward, while $p_{\mathrm{d}}^{\prime}$ continues to play little role without a mature cell (Fig. 17d-f). Now, with clouds reaching about $5 \mathrm{~km}, B$ has become positive at the core of $\mathrm{C} 1$ (peaking over $2 \times 10^{-3} \mathrm{~m} \mathrm{~s}^{-2}$ near $1.5 \mathrm{~km}$ ) due to LHR after saturation (Fig. 18a and b), giving the largest $\theta_{\mathrm{v}}^{\prime}$ of $\sim 1.2 \mathrm{~K}$ (not shown). Near the cloud top and below the cloud base of $C 1$, both $B$ and $\theta_{\mathrm{v}}^{\prime}$ turn negative and can only come from adiabatic or evaporative cooling, or both. The cooling near 5-6 km explains the layer of $\nabla^{2} p_{\mathrm{b}}^{\prime}$ (and $\left.\nabla^{2} p^{\prime}\right)>0$ immediately above (over 6-7 km, Fig. 17d and e), as seen earlier in Fig. 14g and $\mathrm{j}$ above the developing B2 (near $5 \mathrm{~km}$ ). The solutions of $p^{\prime}$ and $p_{\mathrm{b}}^{\prime}$ by the relaxation method, linked to the pattern of their Laplacian noted above, produce downward perturbation PGF (below $\sim 2 \mathrm{~km}$, Fig. $18 \mathrm{c}$ and d) that partially cancels the upward buoyant force (cf. Fig. 18a).

Overall, the warming by LHR and the cooling above during the developing stage of new cells represent a destabilization in their low-level environment with time (Figs. 15 and 18). Forced by the background convergence (cf. Fig. 9), even though $\mathrm{C} 1$ eventually also develops into deep convection, the vertical perturbation PGF remains pointing down below about $2.5 \mathrm{~km}$ even at 21:20 UTC (Fig. 18c and d). In contrast, it is positive above $1-1.5 \mathrm{~km}$ in $\mathrm{B} 2$ and helps its development at both 20:40 and 21:00 UTC (Fig. 16d and g). Consistent with this difference, in B2 the maximum center of $p_{\mathrm{b}}^{\prime}$ occurs closer to the surface and it decreases with height more rapidly above, and three factors linked to the old cell B1 contribute to the establishment of the upward-directed pertur- 

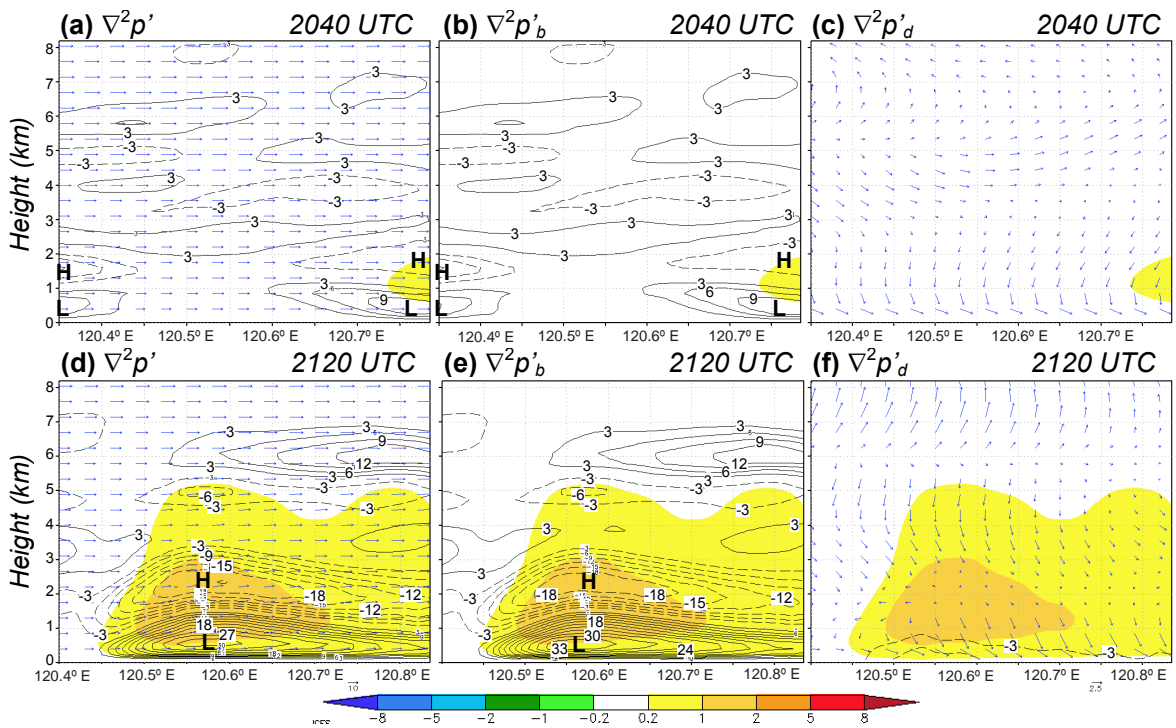

Figure 17. As in Fig. 14, but showing $w\left(\mathrm{~m} \mathrm{~s}^{-1}\right.$, color) and (a) $\nabla^{2} p^{\prime}\left(10^{-6} \mathrm{~Pa} \mathrm{~m}^{-2}\right)$ and wind vectors $\left(\mathrm{m} \mathrm{s}^{-1}\right)$ on section plain, (b) $\nabla^{2} p_{\mathrm{b}}^{\prime}$, and (c) $\nabla^{2} p_{\mathrm{d}}^{\prime}$ and vertical wind shear vector $\left(10^{-3} \mathrm{~s}^{-1}\right.$, in cardinal direction) along the WSW-ENE segment through C1 at 20:40 UTC, 11 June 2012 (cf. Fig. 10). (d-f) As in panels (a-c), except at 21:20 UTC.
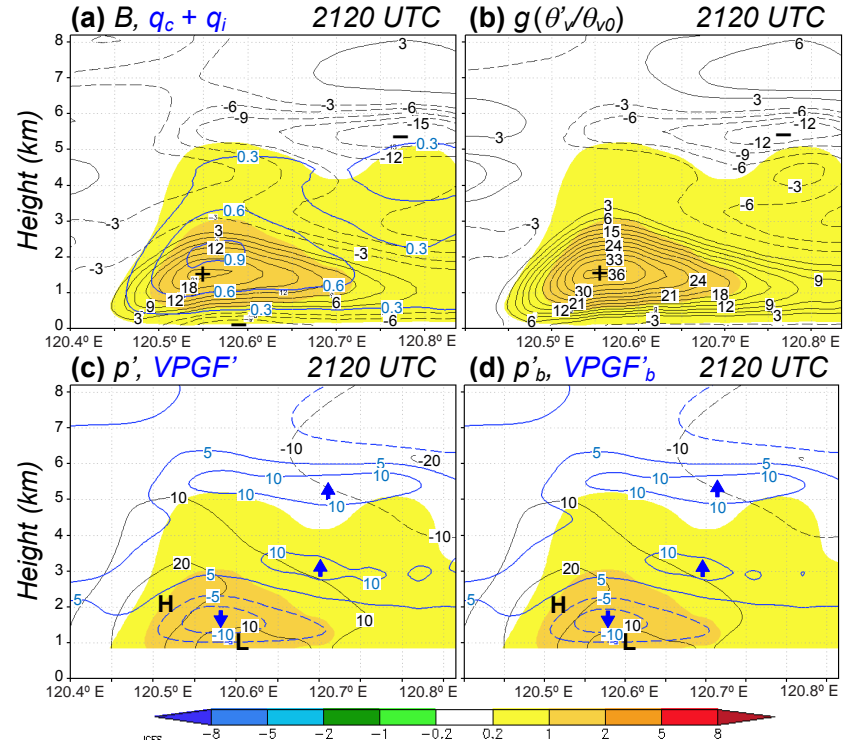

Figure 18. (a, b) As in Fig. 15a and b, but showing $w$ (color) and (a) $B$ (black contour) and mixing ratio of cloud particles (blue contour) and (b) $g\left(\theta_{\mathrm{v}}^{\prime} / \theta_{\mathrm{v} 0}\right)$ along the WSW-ENE segment through C1 at 21:20 UTC, 11 June 2012. (c, d) As in Fig. 16a and b, but showing $w$ and (c) $p^{\prime}$ (black contour) obtain from the relaxation method and $-\left(\partial p^{\prime} / \partial z\right) / \rho_{0}$ (blue contour) and (d) $p_{\mathrm{b}}^{\prime}$ and its vertical PGF along the segment as in panels $(\mathbf{a}, \mathbf{b})$ at 21:20 UTC.

bation PGF. First, a stronger cooling occurs near $3 \mathrm{~km}$ above B2 (Fig. 15), at levels significantly lower than that above C1 (cf. Fig. 18), and this cooling is likely enhanced by evaporation of condensates near the western edge of B1 (besides adiabatic effect). Second, a more rapid and efficient warming also occurs closer to the surface at the early stage of B2, and this is helped by the stronger LHR near the bottom of B1 (cf. Fig. 15). Both these effects can be thought of as a more rapid destabilization that gives the new cell the potential for a faster development. Finally, the separation by the descending branch of the old cell, when such a descent can reach a lower elevation, also plays a role in leading to BB process about $20 \mathrm{~km}$ upstream in the present case, based on our numerical simulation results in this case study. In $\mathrm{C} 1$ where $B>0$ is counteracted by a downward perturbation PGF, all three advantages are absent without a nearby old cell (Figs. 17 and 18).

\section{Conclusion and summary}

During 11-12 June 2012 in the meiyu season, both TL/AS and BB MCSs developed in succession near northern Taiwan and together produced extreme rainfall up to $510 \mathrm{~mm}$ overnight in the Taipei metropolitan area, causing serious flooding in many densely populated regions. Observations show that BB behavior occurred in these MCSs, especially in the second, $\mathrm{E}-\mathrm{W}$-aligned quasistationary linear MCS during 18:00-24:00 UTC, 11 June (02:00-08:00 LST, 12 June), and was a contributing factor to the extreme rainfall and related hazards in Taipei. The numerical simulation using the CReSS model with a horizontal grid size of $1.5 \mathrm{~km}$ starting at 12:00 UTC on 10 June successfully captured the development and evolution of the BB MCS (but with considerable position error for the preceding TL/AS system). In contrast to midlatitude (and some subtropical) systems, the cold pool 
mechanism is not responsible for triggering new BB cells in the present MCS, and thus the model results are used to investigate the details of the BB process occurring specifically about $15-30 \mathrm{~km}$ upstream from old convective elements in this subtropical system.

In agreement with and supported by the observations, the linear BB MCS in the present event was forced by near-surface convergence ahead of the front, between the flow blocked and deflected northward (into southwesterly) by the topography of Taiwan and the unblocked (westsouthwesterly) flow farther to the north and west in the environment. The approaching meiyu front (about $80-30 \mathrm{~km}$ ) to the north of the linear MCS thus helped provide and channel an enhanced prevailing flow to its south but did not play a direct role in the formation of the MCS. While the above processes all worked in synergy and contributed to the heavy rainfall, it is not possible to quantify their individual effect in the present study.

For the BB process at the convective scale, although the dynamic pressure perturbations $\left(p_{\mathrm{d}}^{\prime}\right)$ from the interaction between the mature cells and the LLJ, with $p_{\mathrm{d}}^{\prime}>0(<0)$ at the rear (forward) flank of the updraft near the surface below the jet and a reversed pattern near $2-3 \mathrm{~km}$ above the jet, can cause the mature cells to slowdown slightly and enhance the low-level convergence upstream, their effects are weaker compared to those found in WKJ15 for a case of typhoon rainband, and a direct role in new cell initiation appears quite limited.

In the present event, the total pressure perturbations $\left(p^{\prime}\right)$ in the vicinity of the new cell throughout the initiation stage are attributed more to their buoyant $\left(p_{\mathrm{b}}^{\prime}\right)$ than dynamical component. Forced by the low-level convergence (parallel to the line) in the background, the early development of new cells, at convective scale, is associated with positive buoyancy $(B>0)$ by latent heating below and negative buoyancy $(B<0)$ by adiabatic cooling above, and this represents a gradual destabilization in their surrounding environment. By comparing the $\mathrm{BB}$ process with the initiation of an isolated cell, the additional and specific roles played by the old cell to help trigger new convection to its west can be identified. At the initial stage, the development is close to the mature cell, which provides stronger warming below (and closer to the surface) and also additional cooling above from evaporation of condensates at its rear side. The more rapid upward decrease in $B$ produces a positive $p_{\mathrm{b}}^{\prime}$ at a lower height and subsequently an upward-directed perturbation (buoyant) PGF that drives further development together with the positive buoyancy. Thus, the net effect of the additional warming/cooling is essentially a more rapid destabilization that gives the new cell a faster development. After some time when the new cell has gained sufficient strength, a descending branch appearing at the rear flank of the old cell acts to separate the new cell to about $20 \mathrm{~km}$ upstream. The new cell continues to strengthen there, and eventually deep convection is ignited. Thus, the above roles played by the existing old cells, largely thermodynamic in origin but also helped by dynamical and kinematic effects, can explain why the spot roughly $15-30 \mathrm{~km}$ upstream from the western end of quasilinear MCSs in the subtropics can often have advantages over other locations for new cell initiation in their back-building process, even in the absence of cold pool mechanism. To our knowledge, the above favorable factors that can be provided by the old cells in the BB MCSs, particularly not in association with the cold pool, have not been investigated in the literature before.

\section{Data availability}

The observational data used in this study are available from the Data Bank for Atmospheric and Hydrological Research (https://dbahr.narlabs.org.tw/) or from the CWB (http: //www.cwb.gov.tw/). Outputs of the CReSS simulation can be obtained from CCW by request, or reproduced using the same gridded NCEP and SST data (publicly available) and version 2.3 of CReSS (http://www.rain.hyarc.nagoya-u.ac. jp/ tsuboki/cress_html/index_cress_jpn.html). 


\section{Appendix A: The relaxation method}

In this study, the relaxation method is used to numerically solve for the pressure perturbation $p$ from its 3-D Laplacian $\nabla^{2} p$ ("prime" omitted for simplicity), where $\nabla^{2} p$ can be $\nabla^{2} p_{\mathrm{b}}, \nabla^{2} p_{\mathrm{d}}$, or any of the right-hand side terms in Eqs. (3) or (4). In this appendix, its formulation and BCs are described. Since the vertical grid spacing of CReSS is stretched, the values of $\nabla^{2} p$ (and all other known variables in need) are first vertically interpolated to grid with a fixed $\Delta z$ of $100 \mathrm{~m}$, such that $\Delta x=\Delta y=1 \mathrm{~km}=10 \Delta z$. At second-order accuracy, the 3-D Laplacian inside the calculation domain is approximated by the central-difference method as

$$
\begin{aligned}
\nabla^{2} p= & \frac{p_{x+1}+p_{x-1}-2 p}{\Delta x^{2}}+\frac{p_{y+1}+p_{y-1}-2 p}{\Delta y^{2}} \\
& +\frac{p_{z+1}+p_{z-1}-2 p}{\Delta z^{2}},
\end{aligned}
$$

where subscripts represent the $p$ values of the next grid point on either side in each direction. After rearranging terms to move only $p$ (unknown) on the left-hand side and using $\Delta x=\Delta y=10 \Delta z$, Eq. (A1) can be rewritten as

$p=\frac{p_{x+1}+p_{x-1}+p_{y+1}+p_{y-1}+10^{2}\left(p_{z+1}+p_{z-1}\right)-\left(\Delta x^{2} \times \nabla^{2} p\right)}{4+2 \times 10^{2}}$

and used for interior grid points. On the boundary of the domain, the Neumann condition is applied and the next grid point outside is assumed to have the same value as the one on the boundary. For example, $p_{x-1}=p$ on the western boundary, and the Laplacian in $x$ direction $\left(\nabla^{2} p_{x}\right)$ in Eq. (A1) re- duces to

$\nabla^{2} p_{x}=\frac{p_{x+1}-p}{\Delta x^{2}}$,

while the two other right-hand side terms in $y$ and $z$ directions remain unchanged. So, on the western boundary, the $p_{x-1}$ term vanishes and the formula equivalent to Eq. (A2) becomes

$p=\frac{p_{x+1}+p_{y+1}+p_{y-1}+10^{2}\left(p_{z+1}+p_{z-1}\right)-\left(\Delta x^{2} \times \nabla^{2} p\right)}{3+2 \times 10^{2}}$.

Thus, on each of the remaining sides (and edges and corners) along the boundary of the 3-D domain, the formula would take a different form from Eq. (A2) following a similar derivation. Since the procedures are quite straightforward, they are not repeated here.

Using equations including Eqs. (A2) and (A4), the values of $p$ can be numerically solved through iteration. Starting from a set of first guess of $p$, all the terms on the right-hand side are known or can be computed, and a new set of $p$ on the left-hand side is obtained in each iteration going through all the grid points. After each iteration, Eq. (A1) (or its equivalents on the boundaries) is used to compute $\nabla^{2} p$ from the newly obtained $p$ and check against the true value (from Eqs. 3 or 4). When the total absolute error of $\nabla^{2} p$ summed over all grid points reduces below the specified threshold, the result converges and the iteration stops. Figures 13 and 15 of WKJ15 provide some examples of the results obtained using the same relaxation method. 
Acknowledgements. The authors wish to acknowledge the CWB and NCEP for providing the various data used in this study, the help from C.-Y. Lee in programming, and K.-Y. Chen and S.-Y. Huang for making some of the figures. This study is jointly supported by the Ministry of Science and Technology of Taiwan under grants MOST-103-2119-M-003-001-MY2, MOST-105-2111-M-003-003MY3, and MOST-105-2625-M-003-001.

Edited by: H. Wernli

Reviewed by: three anonymous referees

\section{References}

Bluestein, H. B. and Jain, M. H.: Formation of mesoscale lines of precipitation: severe squall lines in Oklahoma during the spring, J. Atmos. Sci., 42, 1711-1732, 1985.

Brooks, H. E. and Stensrud, D. J.: Climatology of heavy rain events in the United States from hourly precipitation observations, Mon. Weather Rev., 128, 1194-1201, 2000.

Browning, K. A.: Organization of clouds and precipitation in extratropical cyclones, in: Extratropical Cyclones: The Erik Palmén Memorial Volume, edited by: Newton, C. W. and Holopanien, E. O., Am. Meteor. Soc., Boston, MA, USA, 129-153, 1990.

Carbone, R. E.: A severe frontal rainband. Part I: Stormwide hydrodynamic structure, J. Atmos. Sci., 39, 258-279, 1982.

Chappell, C. F.: Quasi-stationary convective events, in: Mesoscale Meteorology and Forecasting, edited by: Ray, P., Am. Meteor. Soc., Boston, MA, USA, 289-310, 1986.

Chen, G. T.-J.: Research on the phenomena of Meiyu during the past quarter century: An overview, World Scientific Series on AsiaPacific Weather and Climate, Volume 2. East Asian Monsoon, edited by: Chang, C.-P., World Scientific, Singapore, 357-403, 2004.

Chen, G. T.-J. and Chou, H.-C.: General characteristics of squall lines observed in TAMEX, Mon. Weather Rev., 121, 726-733, 1993.

Chen, G. T.-J. and Yu, C.-C.: Study of low-level jet and extremely heavy rainfall over northern Taiwan in the mei-yu season, Mon. Weather Rev., 116, 884-891, 1988.

Chen, G. T.-J., Wang, C.-C., and Liu, S. C.-S.: Potential vorticity diagnostics of a Mei-yu front case, Mon. Weather Rev., 131, 26802696, 2003.

Chen, G. T.-J., Wang, C.-C., and Lin, D. T.-W.: Characteristics of low-level jets over northern Taiwan in Mei-yu season and their relationship to heavy rain events, Mon. Weather Rev., 133, 2043, 2005.

Corfidi, S. F.: Cold pools and MCS propagation: forecasting the motion of downwind-developing MCSs, Weather Forecast., 18, 997-1017, 2003.

Corfidi, S. F., Meritt, J. H., and Fritsch, J. M.: Predicting the movement of mesoscale convective complexes, Weather Forecast., 11, 41-46, 1996.

Cotton, W. R., Tripoli, G. J., Rauber, R. M., and Mulvihill, E. A.: Numerical simulation of the effects of varying ice crystal nucleation rates and aggregation processes on orographic snowfall, J. Clim. Appl. Meteorol., 25, 1658-1680, 1986.

Ding, Y.: Summer monsoon rainfalls in China, J. Meteorol. Soc. Jpn., 70, 373-396, 1992.
Ding, Y. and Chan, J. C.-L.: The East Asian summer monsoon: An overview, Meteorol. Atmos. Phys., 89, 117-142, 2005.

Doswell III, C. A.: Severe convective storms - an overview, in: Severe Convective Storms, Meteor. Monogr., No. 50, Am. Meteor. Soc., Boston, MA, USA, 1-26, 2001.

Doswell III, C. A., Brooks, H. E., and Maddox, R. A.: Flash flood forecasting: an ingredients-based methodology, Weather Forecast., 11, 560-581, 1996.

Figa-Saldaña, J., Wilson, J. J. W., Attema, E., Gelsthorpe, R., Drinkwater, M. R., and Stoffelen, A.: The Advanced Scatterometer (ASCAT) on the Meteorological Operational (MetOp) platform: A follow on for the European wind scatterometers, Can. J. Remote Sens., 28, 404-412, 2002.

Fovell, R. G., Mullendore, G. L., and Kim, S.-H.: Discrete propagation in numerically simulated nocturnal squall lines, Mon. Weather Rev., 134, 3735-3752, 2006.

Houston, A. L. and Wilhelmson, R. B.: Observational analysis of the 27 May 1997 central Texas tornadic event. Part I: Prestorm environment and storm maintenance/propagation, Mon. Weather Rev., 135, 701-726, 2007.

Houze Jr., R. A., Smull, B. F., and Dodge, P.: Mesoscale organization of springtime rainstorms in Oklahoma, Mon. Weather. Rev., 118, 613-654, 1990.

Hsu, J.: ARMTS up and running in Taiwan, Väisälä News, 146, 24 26, 1998.

Ikawa, M. and Saito, K.: Description of a nonhydrostatic model developed at the Forecast Research Department of the MRI, MRI Tech. Rep. 28, Tsukuba, Japan, 238 pp., 1991.

James, R. P. and Markowski, P. M.: A numerical investigation of the effects of dry air aloft on deep convection, Mon. Weather Rev., 138, 140-161, 2010.

Jeong, J.-H., Lee, D.-I., and Wang, C.-C.: Impact of cold pool on mesoscale convective system produced extreme rainfall over southeastern South Korea: 7 July 2009, Mon. Weather Rev., in press, doi:10.1175/MWR-D-16-0131.1, 2016.

Johnson, R. H. and Mapes, B. E.: Mesoscale processes and severe convective weather, in: Severe Convective Storms, edited by: Doswell III, C. A., Meteor. Monogr., No. 50, Am. Meteor. Soc., Boston, MA, USA, 71-122, 2001.

Jou, B. J.-D. and Deng, S.-M.: Structure of a low-level jet and its role in triggering and organizing moist convection over Taiwan: A TAMEX case study, Terr. Atmos. Oceanic Sci., 3, 39-58, 1992.

Klemp, J. B.: Dynamics of tornadic thunderstorms, Annu. Rev. Fluid Mech., 19, 369-402, 1987.

Kondo, J.: Heat balance of the China Sea during the air mass transformation experiment, J. Meteorol. Soc. Jpn., 54, 382-398, 1976.

Kuo, Y.-H. and Anthes, R. A.: Numerical simulation of a MeiYu system over southeastern Asia, Pap. Meteor. Res., 5, 15-36, 1982.

Kuo, Y.-H. and Chen, G. T.-J.: The Taiwan Area Mesoscale Experiment (TAMEX): An overview, B. Am. Meteorol. Soc., 71, 488-503, 1990.

LeMone, M. A., Zipser, E. J., and Trier, S. B.: The role of environmental shear and thermodynamic conditions in determining the structure and evolution of mesoscale convective systems during TOGA COARE, J. Atmos. Sci., 55, 3493-3518, 1998.

Li, J. and Chen, Y.-L.: Barrier jets during TAMEX, Mon. Weather Rev., 126, 959-971, 1998. 
Li, J., Chen, Y.-L., and Lee, W.-C.: Analysis of a heavy rainfall event during TAMEX, Mon. Weather Rev., 125, 1060-1082, 1997.

Lin, Y.-L., Farley, R. D., and Orville, H. D.: Bulk parameterization of the snow field in a cloud model, J. Clim. Appl. Meteorol., 22, 1065-1092, 1983.

Louis, J. F., Tiedtke, M., and Geleyn, J. F.: A short history of the operational PBL - parameterization at ECMWF, in: Proceedings, ECMWF Workshop on Planetary Boundary Layer Parameterization, 25-27 November 1981, Reading, UK, 59-79, 1981.

Luo, Y., Gong, Y., and Zhang, D.-L.: Initiation and organizational modes of an extreme-rain-producing mesoscale convective system along a Mei-yu front in East China, Mon. Weather Rev., 142, 203-221, 2014.

Maddox, R. A., Chappell, C. F., and Hoxit, L. R.: Synoptic and meso- $\alpha$ scale aspects of flash flood events, B. Am. Meteorol. Soc., 60, 115-123, 1979.

Meng, Z., Yan, D., and Zhang, Y.: General features of squall lines in East China, Mon. Weather Rev., 141, 1629-1647, 2013.

Moore, B. J., Neiman, P. J., Ralph, F. M., and Barthold, F. E.: Physical processes associated with heavy flooding rainfall in Nashville, Tennessee, and vicinity during 1-2 May 2010: The role of an atmospheric river and mesoscale convective systems, Mon. Weather Rev., 140, 358-378, 2012.

Morrison, H., Thompson, G., and Tatarskii, V.: Impact of cloud microphysics on the development of trailing stratiform precipitation in a simulated squall line: Comparison of one- and two-moment schemes, Mon. Weather Rev., 137, 991-1007, 2009.

Murakami, M.: Numerical modeling of dynamical and microphysical evolution of an isolated convective cloud - The 19 July 1981 CCOPE cloud, J. Meteorol. Soc. Jpn., 68, 107-128, 1990.

Murakami, M., Clark, T. L., and Hall, W. D.: Numerical simulations of convective snow clouds over the Sea of Japan: twodimensional simulation of mixed layer development and convective snow cloud formation, J. Meteorol. Soc. Jpn., 72, 43-62, 1994.

Parker, M. D. and Johnson, R. H.: Organizational modes of midlatitude mesoscale convective systems, Mon. Weather Rev., 128, 3413-3436, 2000.

Parker, M. D. and Johnson, R. H.: Structures and dynamics of quasi2D mesoscale convective systems, J. Atmos. Sci., 61, 545-567, 2004.

Peters, J. M. and Roebber, P. J.: Synoptic control of heavy-rainproducing convective training episodes, Mon. Weather Rev., 142, 2464-2482, 2014.

Peters, J. M. and Schumacher, R. S.: Mechanisms for organization and echo training in a flash-flood-producing mesoscale convective system, Mon. Weather Rev., 143, 1058-1085, 2015.

Reynolds, R. W., Rayner, N. A., Smith, T. M., Stokes, D. C., and Wang, W.: An improved in situ and satellite SST analysis for climate, J. Climate, 15, 1609-1625, 2002.

Rotunno, R. and Klemp, J. B.: The influence of the shear-induced pressure gradient on thunderstorm motion, Mon. Weather Rev., 110, 136-151, 1982.

Rotunno, R., Klemp, J. B., and Weisman, M. L.: A theory for strong, long-lived squall lines, J. Atmos. Sci., 45, 463-485, 1988.

Schumacher, R. S. and Johnson, R. H.: Organization and environmental properties of extreme-rain-producing mesoscale convective systems, Mon. Weather Rev., 133, 961-976, 2005.
Schumacher, R. S. and Johnson, R. H.: Characteristics of U.S. extreme rain events during 1999-2003, Weather Forecast., 21, 6985, 2006.

Schumacher, R. S. and Johnson, R. H.: Quasi-stationary, extremerain-producing convective systems associated with midlevel cyclonic circulations, Weather Forecast., 24, 555-574, 2009.

Schumacher, R. S., Galarneau Jr., T. J., and Bosart, L. F.: Distant effects of a recurving tropical cyclones on rainfall in a midlatitude convective system: A high-impact predecessor rain event, Mon. Weather Rev., 139, 650-667, 2011.

Segami, A., Kurihara, K., Nakamura, H., Ueno, M., Takano, I., and Tatsumi, Y.: Operational mesoscale weather prediction with Japan Spectral Model, J. Meteorol. Soc. Jpn., 67, 907-924, 1989.

Stevenson, S. N. and Schumacher, R. S.: A 10-year survey of extreme rainfall events in the central and eastern United States using gridded multisensor precipitation analyses, Mon. Weather Rev., 142, 3147-3162, 2014.

Sun, J. and Lee, T.-Y.: A numerical study of an intense quasistationary convection band over the Korean Peninsula, J. Meteorol. Soc. Jpn., 80, 1221-1245, 2002.

Tompkins, A. M.: Organization of tropical convection in low vertical wind shears: The role of cold pools, J. Atmos. Sci., 58, 1650 1672, 2001.

Tsuboki, K. and Sakakibara, A.: Large-scale parallel computing of cloud resolving storm simulator, in: High Performance Computing, edited by: Zima, H. P., Joe, K., Sato, M., Seo, Y., and Shimasaki, M., Springer-Verlag, Berlin and Heidelberg, Germany, New York, NY, USA, 243-259, 2002.

Tsuboki, K. and Sakakibara, A.: Numerical Prediction of HighImpact Weather Systems: the Textbook for the Seventeenth IHP Training Course in 2007, Hydrospheric Atmospheric Research Center, Nagoya University and UNESCO, Nagoya, Japan, 273 pp., 2007.

Wang, C.-C.: The more rain, the better the model performs - The dependency of quantitative precipitation forecast skill on rainfall amount for typhoons in Taiwan, Mon. Weather Rev., 143, 17231748, 2015.

Wang, C.-C.: Paper of notes: The more rain from typhoons, the better the models perform, B. Am. Meteorol. Soc., 97, 16-17, 2016.

Wang, C.-C. and Chen, G. T.-J.: Case study of the leeside mesolow and mesocyclone in TAMEX, Mon. Weather Rev., 130, 2572 2592, 2002.

Wang, C.-C. and Huang, W.-M.: High-resolution simulation of a nocturnal narrow convective line off the southeastern coast of Taiwan in the mei-yu season, Geophys. Res. Lett., 36, L06815, doi:10.1029/2008GL037147, 2009.

Wang, C.-C., Chen, G. T.-J., Chen, T.-C., and Tsuboki, K.: A numerical study on the effects of Taiwan topography on a convective line during the mei-yu season, Mon. Weather Rev., 133, 3217 3242, 2005.

Wang, C.-C., Chen, G. T.-J., and Huang, S.-Y.: Remote trigger of deep convection by cold outflow over the Taiwan Strait in the Mei-yu season: A modeling study of the 8 June 2007 case, Mon Weather Rev., 139, 2854-2875, 2011.

Wang, C.-C., Kuo, H.-C., Chen, Y.-H., Huang, H.-L., Chung, C.-H., and Tsuboki, K.: Effects of asymmetric latent heating on typhoon movement crossing Taiwan: The case of Morakot (2009) with extreme rainfall, J. Atmos. Sci., 69, 3172-3196, 2012. 
Wang, C.-C., Kuo, H.-C., Yeh, T.-C., Chung, C.-H., Chen, Y.-H., Huang, S.-Y., Wang, Y.-W., and Liu, C.-H.: Highresolution quantitative precipitation forecasts and simulations by the Cloud-Resolving Storm Simulator (CReSS) for Typhoon Morakot (2009), J. Hydrol., 506, 26-41, doi:10.1016/j.jhydrol.2013.02.018, 2013.

Wang, C.-C., Hsu, J. C.-S., Chen, G. T.-J., and Lee, D.-I.: A study of two propagating heavy-rainfall episodes near Taiwan during SoWMEX/TiMREX IOP-8 in June 2008. Part I: Synoptic evolution, episode propagation, and model control simulation, Mon. Weather Rev., 142, 2619-2643, 2014a.

Wang, C.-C., Hsu, J. C.-S., Chen, G. T.-J., and Lee, D.-I.: A study of two propagating heavy-rainfall episodes near Taiwan during SoWMEX/TiMREX IOP-8 in June 2008. Part II: Sensitivity tests on the roles of synoptic conditions and topographic effects, Mon. Weather Rev., 142, 2644-2664, 2014b.

Wang, C.-C., Kuo, H.-C., Johnson, R. H., Lee, C.-Y., Huang, S.-Y., and Chen, Y.-H.: A numerical study of convection in rainbands of Typhoon Morakot (2009) with extreme rainfall: roles of pressure perturbations with low-level wind maxima, Atmos. Chem. Phys., 15, 11097-11115, doi:10.5194/acp-15-11097-2015, 2015.

Wang, C.-C., Huang, S.-Y., Chen, S.-H., Chang, C.-S., and Tsuboki, K.: Cloud-resolving typhoon rainfall ensemble forecasts for Taiwan with large domain and extended range through time-lagged approach, Weather Forecast., 31, 151-172, 2016a.

Wang, C.-C., Chen, G. T.-J., and Ho, K.-H.: A diagnostic case study of mei-yu frontal retreat and associated low development near Taiwan, Mon. Weather Rev., 144, 2327-2349, 2016b.

Wang, H., Luo, Y.-L., and Jou, B. J.-D.: Initiation, maintenance, and properties of convection in an extreme rainfall event during SCMREX: observational analysis, J. Geophys. Res.-Atmos., 119, 13206-13232, doi:10.1002/2014JD022339, 2014.
Weisman, M. L. and Klemp, J. B.: Characteristics of isolated convective storms, in: Mesoscale Meteorology and Forecasting, edited by: Ray, P. S., Am. Meteor. Soc., Boston, MA, USA, 331358, 1986.

Weisman, M. L. and Rotunno, R.: "A theory for strong long-lived squall lines" revisited, J. Atmos. Sci., 61, 361-382, 2004.

Wilhelmson, R. B. and Ogura, Y.: The pressure perturbation and the numerical modeling of a cloud, J. Atmos. Sci., 29, 1295-1307, 1972.

Xu, W., Zipser, E. J., Chen, Y.-L., Liu, C., Liou, Y.-C., Lee, W.-C., and Jou, B. J.-D.: An orography-associated extreme rainfall event during TiMREX: Initiation, storm evolution, and maintenance, Mon. Weather Rev., 140, 2555-2574, 2012.

Yang, M.-J. and Houze Jr., R. A.: Multicell squall-line structure as a manifestation of vertically trapped gravity waves, Mon. Weather Rev., 123, 641-661, 1995.

Yeh, H.-C. and Chen, Y.-L.: The role of offshore convergence on coastal rainfall during TAMEX IOP 3, Mon. Weather Rev., 130, 2709-2730, 2002.

Yu, C.-K. and Chen, Y.: Surface fluctuations associated with tropical cyclone rainbands observed near Taiwan during 2000-08, J. Atmos. Sci., 68, 1568-1585, 2011.

Zhang, M. and Zhang, D.-L.: Subkilometer simulation of a torrential-rain-producing mesoscale convective system in East China. Part I: Model verification and convective organization, Mon. Weather Rev., 140, 184-201, 2012. 